\title{
Review of Studies on Thermal Comfort in Indian Residential Buildings
}

\author{
Sunil K. Sansaniwal \\ Jyotirmay Mathur \\ Vishal Garg \\ Rajat Gupta
}

\begin{abstract}
This paper presents a systematic review on thermal comfort studies in Indian residential buildings, to identify the present research scenario, data gaps and policy interventions. Majority of the studies are performed in composite climate (ten), followed by warm-humid (seven) and a very few from cold (two) and hot-dry (two) climates. None thermal comfort study is found in the temperate climate. Seven studies have considered multiple climates for assessment of thermal comfort in residential buildings. This shows that thermal comfort studies in Indian residential buildings are scarce, scattered and unorganized. Further, due to differences in socio-cultural set-up and local adaptations, the prodigious variations in occupant's comfort requirements are reported. This review argues for the dynamic modifications in individual behaviours due to change in cost of building energy services and comfort requirements. Only four studies have partially considered the occupant behaviour regarding control of indoor thermal environment. The results obtained from these studies indicate that there is strong need of localised thermal comfort model that will not only help in improving comfort requirements but also building energy performance. Importantly this review paves way for harmonised thermal comfort research in India where majority of the residential building stock is yet to be built.
\end{abstract}

Keywords: Human thermal comfort, field studies, literature search, methods and parameters, residential buildings 


\begin{tabular}{|c|c|}
\hline Nomenclature & \\
\hline $\mathrm{AC}=$ Air-conditioned & $\mathrm{PPD}=$ Predicted percentage of dissatisfied \\
\hline AMV = Actual mean vote & RAT $=$ Room air temperature $\left({ }^{\circ} \mathrm{C}\right)$ \\
\hline 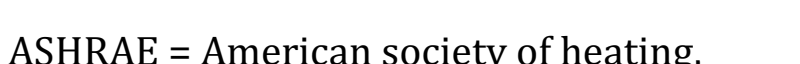 & $\mathrm{RH}=$ Relative humidity $(\%)$ \\
\hline refrigerating and air-conditioning engineers & SET $=$ Standard effective temperature $\left({ }^{\circ} \mathrm{C}\right)$ \\
\hline CFD = Computational fluid dynamics & TPV = Thermal preference vote \\
\hline CIBSE $=$ Chartered Institution of Building & TSI = Tropical summer index \\
\hline Services Engineers & TSV = Thermal sensation vote \\
\hline $\mathrm{DBT}=$ Dry bulb temperature $\left({ }^{\circ} \mathrm{C}\right)$ & $T_{a v g}=$ Average indoor temperatures $\left({ }^{\circ} \mathrm{C}\right)$ \\
\hline ECBC = Energy conservation building code & $S_{w g}=$ Temperature swing $\left({ }^{\circ} \mathrm{C}\right)$ \\
\hline $\begin{array}{l}\text { ePMV }=\text { Expected predicted mean vote } \\
\text { GT, } T_{g}=\text { Globe temperature }\left({ }^{\circ} \mathrm{C}\right)\end{array}$ & $\begin{array}{l}T_{\max }=\text { Outdoor maximum temperature }\left({ }^{\circ} \mathrm{C}\right) \\
I l l=\text { Factor }\end{array}$ \\
\hline IEQ = Indoor environmental quality & $T_{\text {com }}=$ Comfort temperature $\left({ }^{\circ} \mathrm{C}\right)$ \\
\hline ISHRAE = Indian society of heating, & $T_{m}=$ Mean monthly outdoor temperature $\left({ }^{\circ} \mathrm{C}\right)$ \\
\hline refrigerating and air-conditioning engineers & $T_{n}=$ Neutral temperature $\left({ }^{\circ} \mathrm{C}\right)$ \\
\hline ISO = International organization for & WBT $=$ Wet Bulb Temperature $\left({ }^{\circ} \mathrm{C}\right)$ \\
\hline standardization & \\
\hline LIG = Low income group & r velocity (m/s) \\
\hline MM = Mixed mode & $T_{O}=$ Outdoor air temperature $\left({ }^{\circ} \mathrm{C}\right)$ \\
\hline $\mathrm{MRT}=$ Mean radiant temperatures $\left({ }^{\circ} \mathrm{C}\right)$ & $T_{a}=$ Indoor air temperature $\left({ }^{\circ} \mathrm{C}\right)$ \\
\hline NBC = National building code & $T_{o p}=$ Operative temperature $\left({ }^{\circ} \mathrm{C}\right)$ \\
\hline NV = Naturally ventilated & M = Metabolic \\
\hline $\mathrm{OT}=$ Operative temperature $\left({ }^{\circ} \mathrm{C}\right)$ & $q_{M}=$ Metabolic heat rate $\left(\mathrm{W} / \mathrm{m}^{2}\right)$ \\
\hline PCM = Phase change material & $q_{j}=$ Human heat loss $\left(\mathrm{W} / \mathrm{m}^{2}\right)$ \\
\hline PMV = Predicted mean vote & \\
\hline
\end{tabular}




\section{Introduction}

Among Asia Pacific Partnership countries, India has the highest residential building energy consumption and likely to be increased with the addition of new building stock (Bin and Evans, 2008). In Indian dwellings, about 73\% of total energy consumption is used for HVAC and lighting to meet the requirements of thermal and visual comforts (ECBC, 2007). India has diversified socio-cultural set-up and climatic conditions that provides several opportunities to people to drive their livelihood and healthy lifestyle (Kumar et al., 2017). The Indian climate has extraordinary variety ranging from tropical in south to temperate in north. It is strongly influenced by the Himalayas in north, the Thar Desert in North-West directions and the sea in South (Rao and Patil, 2016). India has five designated climatic zones i.e. hot-dry, warm-humid, composite, cold and temperate (NBC, 2015). The requirement of human thermal comfort greatly varies with climatic zones having disparity of environmental conditions.

The occupant's expectations for thermal comfort also vary considerably and hence, the building energy consumption. In Indian residential buildings, about $45 \%$ of energy is used to meet the requirements of thermal comfort (ECBC, 2007). With high growth rate in modern infrastructure and residential building stock, the residential energy demand is likely to be increased in future. Thermal comfort is "the state of mind that expresses satisfaction within the thermal environment" and generally assessed subjectively (ASHRAE, 2004). It generally depends on six parameters i.e. four environmental parameters (RAT, MRT, air velocity and RH) and two personal parameters (clothing level and metabolic activities) (ISO, 2005).

The adaptive model (amalgamation of physiological, psychological and behavioural aspects) can significantly decrease the building space cooling requirements. It is based on the fundamental of adaptability which states that if a person feel discomfort due to change of conditions, he/she will react to restore the comfort level (Roaf et al., 2012). The adaptive model considers the dynamic variations of both internal and external environmental conditions including the individual behaviour using the field study data of real buildings (Fabbri, 2015; Djongyang et al., 2010). However, the socio-cultural aspects, thermal history, income and context are not comprehensively considered in the existing thermal comfort model. The adaptive thermal comfort model was also incorporated in ASHRAE 55 (ASHRAE, 2004). 
Such stimulus not only helps in saving the building energy consumption but also abate greenhouse gases emitted by the buildings. Both heat balance and adaptive approaches have been implemented by studies on thermal comfort in India but the generalisation of adaptation for different climatic zones has been the topic of discussion. Besides, the building forms and types notably influence the indoor environment of building. In India, the building stock is heavily diversified ranging from the heritage buildings to the modern buildings. With the rise of population, the housing sector in India has been among the fastest growing sectors (Manoj, 2004).

The residential buildings in India can be grouped into several ways based on the construction materials, height, layouts and ventilation mode (National Disaster Management Authority, 2013). Based on the heights, these buildings are classified as low and high rise buildings. The high rise buildings have the height above $15 \mathrm{~m}$ while the low rise building have the height below $15 \mathrm{~m}$ (NBC, 2005). Based on the layouts, these buildings are classified as row houses, semi-detached or detached house. According to the ventilation mode, the residential buildings are grouped as NV and MM buildings. In NV buildings, the natural force creates free flow of air and maintains thermal comfort in built space. In MM buildings, the natural and air-conditioning processes are combined used or switched to either as per the user's requirement (Zhao et al., 2018).

Unfortunately, there is no thermal comfort standard specific to Indian context. The standards advocated in Indian codes (i.e. NBC) are based on ASHRAE 55 (ASHRAE, 2004) and ISO7730 (ISO, 2005) standards which generally do focus on western culture and thus, has been criticized for their systematic discrepancies (Manu et al., 2016). The range of comfort temperature $\left(26-32^{\circ} \mathrm{C}\right)$ obtained for Indian context is way above the values (i.e. $21-23^{\circ} \mathrm{C}$ for winter and $23-26^{\circ} \mathrm{C}$ for summer), as specified by NBC and was applicable for air-conditioned buildings only (NBC, 2005). Later, the revision of NBC (NBC, 2016) proposed the formula for determining comforts temperature for all type of buildings based on the outside mean temperature. Some efforts like India Model for Adaptive Comfort (IMAC, 2014) focusing mainly on adaptive characteristics has drawn thermal comfort guidelines particularly for NV and AC office buildings in India. The field study was carried put in 16 office buildings in five representative cities located under five designated climatic zones of India. A total of 6330 thermal comfort survey and 2002 building use studies responses were collected in these buildings. Range of comfort 
temperature obtained for $\mathrm{NV}$ office buildings was $19.6-28.5^{\circ} \mathrm{C}$ for outdoor mean air temperature of $12.5-31^{\circ} \mathrm{C}$ and for $\mathrm{MM}$ office buildings, the range of comfort temperature was $21.5-28.7^{\circ} \mathrm{C}$ for outdoor mean air temperature of $13-38.5^{\circ} \mathrm{C}$ (Manu et al., 2016). This shows that the occupants in office buildings in India are more adaptive and tolerant of mild temperatures. Moreover, the model offers the pathway for building energy efficiency without compromising with occupant's thermal comfort. The results obtained from this model have also been incorporated in NBC Sustainability Chapter (NBC, 2016). However, the scope of applicability of this model is yet to be identified for different climatic zones of India. Therefore, it is worth to review the practices for human thermal comfort affected by exogenous factors (i.e. occupant behaviour, climate, income and socio-cultural). This article presents the review of contemporary research on thermal comfort specific to Indian dwellings. It comprises the details of each study including the sample size, geographical location, method used and the findings. This review identifies the gaps and opportunities for creating new research pathways related to thermal comfort in Indian dwellings.

\section{Thermal comfort standards and models}

\subsection{Thermal comfort standards}

This section covers the brief introduction of widely used thermal comfort standards. At present, the ASHRAE 55 and ISO7730 are globally used thermal comfort standards. Other building standards and codes (i.e. NBC India, ISHRAE IEQ and CIBSE) apprehending the local comfort parameters, have also been adopted in different parts of the world. However, the systematic discrepancies regarding implementation of these standards have been observed due to inadequate consideration of adaptive behaviour which substantially depends on socio-cultural set-up and local adaptation (Parsons, 2001). The brief introduction of widely adopted standards particularly the ASHRAE 55, ISO7730 and CEN EN16798 are presented here:

\section{A. ANSI/ASHRAE Standard 55}

It was first published in 1966 and primarily used in USA but it has become the well-known standard which is widely used for designing, commissioning and testing of indoor environments. It defines thermal comfort as the state of mind that that expresses satisfaction within the thermal environment'. ASHRAE 55 specifies the combination of personal and environmental factors to produce the acceptable 
conditions of indoor thermal environment suitable to majority of occupants (> 80\%) exposed to identical environmental conditions within a space (ASHRAE, 2017). The dissatisfaction limit based on differences in thermal preference of individuals is also specified in the standard. However, it has not covered the effect of non-thermal environment on human health (Olesen and Brager, 2004). Based on research advancements and practical experience, the ASHRAE 55 gets updated every three to seven years and the present notable versions of standard are 2004, 2010 and 2017.

In ASHRAE 55-2004, the criteria gaps between ISO standard and ASHRAE 55 were updated and thus, introduced the computer based adaptive model which relates indoor temperature with ambient parameters. This model also recognised the effect of increased airspeed on occupant thermal comfort particularly in NV spaces (ASHRAE, 2004). ASHRAE 55-2010 updated the method of determining cooling effect due to increased airspeed and air movement in indoor space, by reintroducing the term SET. The general occupant's satisfaction survey and POE method used for pre-emptively and retroactively evaluations of thermal comfort in indoor space (ASHRAE, 2010). ASHRAE 55-2017 has introduced the new element for accounting the change in occupant's thermal comfort due to direct solar. Moreover, the ASHRAE 55 was mainly designed for evaluation of thermal comfort for sedentary occupants in space (ASHRAE, 2017). However, it can be extended to cover other indoor environments except extreme conditions which can be found in ISO 7243, ISO 7933 and ISO/TR 11079.

\section{B. ISO 7730}

The ISO standards on thermal comfort were developed by the technical committee of physical environment ISO/TC/159 SC5 WG1 of which ISO7730 is the most notable that deals with analytical evaluation of thermal comfort based on PMV, PPD and local criteria. ISO 7730:2005 is the third revised edition which has introduced the procedure for long term evaluation of thermal comfort and the concepts of local thermal discomfort, unsteady environmental conditions and adaptation. This standard represents the method for predicting thermal sensation and thermal dissatisfaction of healthy occupants exposed to moderate thermal conditions where thermal comfort is desirable. The acceptable environmental conditions thus recommended by the standard are applicable for both general thermal comfort and local discomfort (ISO, 2005). Occupant's thermal sensation depends on thermal balance affected by personal factors 
(clothing insulation and metabolism activities) and environmental parameters (RAT, MRT, RH and air velocity).

Considering these factors, the general thermal comfort can be estimated by calculating PMV index. The PPD index can be obtained from PMV index and determines the percentage of thermally dissatisfied people feeling too cold and too hot in the prevailing environment. The undesirable cooling or heating of body also leads to local thermal discomfort. The draught causing local cooling of body on account of elevated airspeed is the most common phenomena attributed to local thermal discomfort. This standard also quantifies the dissatisfaction of people due to draught, using model of draught which is based on RAT, air velocity and turbulence intensity at different levels of body (i.e. neck, waist and ankle levels). Besides working environment, IS07730 is also applicable to other types of environment and should be used apropos to ISO/TS 14415:2005, 4.2, for occupants with special requirements i.e. physical disability. Moreover, the standard is widely adopted with good approximation; however, the ethnic and nation-geographical variations should be considered particularly in unconditioned spaces and need further investigations.

\section{European standard (CEN EN16798)}

It is the updated version of standard EN15251 (CEN, 2007) that is generally used for the design of residential and non-residential buildings. The criterion for thermal comfort and indoor air quality given in the earlier standards (IS07730; CR1752) are competent for developing control strategies for HVAC units and building dimensioning. However, they have not covered the variations in occupant's thermal expectations in NV and AC spaces. Further, the year-round prediction of energy demand and indoor thermal comfort may not be directly obtained through these standards. The widely accredited standard CEN EN15251-2007 emphasises on indoor environment, energy calculations and building operation (Nicol and Wilson, 2011). The updated version CEN EN16798-2019 systematizes the methodology for investigating building energy performance, following the mandate of energy performance of building standards.

The predefined PMV and PPD calculations obtained through ASHRAE 55 and IS07730 have been considered as the base for thermal criteria in EN16798-2019. The heating and cooling load calculations, building energy balance and equipment sizing are based on these calculations. Further, the standard covers the specific requirements of IEQ elements (including thermal comfort, indoor air quality, lighting and acoustic 
comforts) with reference to building design. The updated version is divided into two parts namely, Part 1 (normative) and Part 2 (technical). Besides, the new section focusing on daylight factors and occupancy schedules has been included within the annex. This standard has also considered the variations for occupant's thermal expectations obtained for $\mathrm{NV}$ and $\mathrm{MM}$ spaces, in addition to year-round prediction of indoor thermal comfort (CEN, 2019).

\subsection{Thermal comfort models}

The earlier mentioned standards predominantly depend on heat balance approach studied by Fanger at large scale in laboratory environment on healthy people (ASHRAE, 2017; ISO, 2005; CEN, 2007). As a result of this approach, the PMV-PPD model was developed and later applied to field studies. However, the results were widely deviated because of incompliance of assumptions (such as controlled environment, alike responses of subjects in all buildings and thermal state of mind is the function of body's thermal balance) made in PMV-PMD model (de Dear et al., 2013; Yau and Chew, 2014). Influence of various socio-cultural and contextual factors attributed to local adaptation was not considered in the model and thus, resulted into several discrepancies in the results (de Dear et al., 2013). Adaptive thermal comfort model on the other hand was later developed in late 80's for the transient environmental conditions in the field. The contextual behaviour of environment and individual adaptation to the thermal environment were given due consideration in determining the requirements of thermal comfort (Humphreys, 1976). Brief details of Fanger's heat balance model and adaptive thermal comfort models are given as follows:

\section{A. Fanger's heat balance model}

Human body produces heat and exchange it with the surrounding environment. The heat losses thus takes place through diffusion and evaporation processes. The human dynamic thermoregulatory system tries to maintain the average core body temperature of around $37^{\circ} \mathrm{C}$ even when thermal disturbances occurs (Perk, 2005). Thereby, the body need to satisfy certain conditions such as body heat balance, fixed limits of MRT and sweat rate and absence of local thermal discomfort, required to achieve thermal comfort (Alfano, 2018). In 1970s, the P. O. Fanger identified these conditions and developed a thermal comfort equation knowing as 'Fanger's comfort equation' which quantitatively combined the personal and environmental variables. The 
PMV and PPD calculations were made through the studies of 1296 subjects and later these calculations were standardized in ISO7730 (Fanger, 1970; ISO, 2005). The PMV obtained from the Fanger's comfort equation expresses the occupant's judgement with regards to the given environmental conditions. The PMV calculation was based on heat balance of human body with surrounding environment and is expressed as (Schaudienst and Vogdt, 2017):

$$
P M V=[0.303 \times \exp (-0.036 M)+0.028]\left(q_{M}-q_{j}\right)
$$

Whereas the PPD predicted the percentage of dissatisfied people with a given thermal environment and can be obtained from PMV index. It can be determined using the following equation for a given environment.

$$
P P D=100-95^{\left(-0.03353 \times P M V^{4}-0.2179 \times P M V^{2}\right)}
$$

In typical climatic condition, the human heat loss through convective and radiative heat transfers in an office building can be up to $65-75 \%$. Thus, the clothing and environment should be relevant to the human warmth. Further, the metabolic heat production accounting respiration and evaporation rate is given by (where the mechanical power denoted by $\mathrm{W}$ can be neglected for most of the activities):

$$
q_{M}=M-W
$$

The metabolic heat expressing the level of thermal activities is represented in unit 'met' $(1$ met $=58.15 \mathrm{~W} / \mathrm{m} 2)$ (Gagge, 1941). The corresponding resting metabolic heat (RMR) is measured for the standardized person sitting in a relaxed position (Ainsworth et al., 1993).

$$
M=M E T \times R M R
$$

The Fanger's model of thermal comfort is applicable to standardized people and climatic conditions. It had been introduced in several studies carried out for investigation of thermal comfort both in experimental chambers and real-life situations (Alfano, 2018). Many of these studies have supported the model and others showed some discrepancies regarding model as whole, input parameters and model applicability in different kinds of buildings and environmental conditions (de Dear et al., 2013). However, the environmental engineering practice needs a predictive method which is applicable to all types of buildings, environmental conditions and people. 


\section{B. Adaptive model}

This model is based on adaptive principle which states that if any change causing discomfort occurs, the people response in ways to restore their level of comfort. The adaptive concept is linked with the findings of field surveys conducted in wide range of environments. These surveys deal with the physical measurement of thermal environment and occupant's subjective response regarding thermal environment. The data thus obtained is statistically analysed for predicting the comfort range of thermal variables such as RAT, RH and air velocity (Sharma and Ali, 1986). Adaptive approach determines the range of comfort temperature by linking comfort vote to occupant's response. Comfort temperature depends on the interaction between occupants and building attributes (like window, door, fan etc.) or other environments. There are numerous factors which can influence the occupant responses to the prevailing environment and hence, the comfort temperature can be changed (Nicol and Humphreys, 2002). The primary contextual variable in thermal comfort studies is the climate which impacts on thermal attitude of occupant and design of building. However, the climate may not change the basic mechanisms of interaction between occupant and thermal environment. There are several ways in which the living climate can influence the occupant responses towards the indoor climate. The building forms, building types and building services plays critical role in defining the survey results. Another influencing factor is time as the occupant responses and activities occur in a set time frame (Nicol and Humphreys, 2002).

Further, the meta-analyses of comfort surveys also help to draw different interferences from large volume of restricted surveys on thermal comfort. However, field study has some bottlenecks related to inaccurate measurement of environmental conditions and generalisation of survey results as two different surveys can never give similar outcomes even for the identical environmental conditions. The inaccuracy in measuring data also leads to errors in establishing the relationship among thermal variables (Humphreys and Nicol, 2000). Buildings in India are occupied by people of diversified culture and adaptive behaviour. These buildings are of different types and forms and located under different climatic zones. The range of comfort temperature obtained for these buildings is wide which not only meets the occupant comfort requirements but also substantially reduces the building energy consumption. In India, the largest stock of buildings including both old and new buildings is of NV types; 
however, there has been a lack of a contextual model for adaptive thermal comfort for India. Although, the IMAC model has quantified the adaptive characteristics but its scope is limited to office buildings only. Therefore, more efforts are required towards development of such models particularly for residential buildings in India.

\section{International scenario of research on thermal comfort}

Research on thermal comfort has undergone a considerable growth and thus, the topic of thermal comfort has been of great interest among the scientific communities (engineering, architecture, social science etc.) particularly in past two decades. The augmentation of peer-reviewed literature reflects the enormous focus on building environments. The policy intervention in building construction practices has further increased the research and development services and entrepreneurship. Availability of huge literature signifies the dramatic growth in our knowledge regarding thermal comfort; however, it may not be meaningful to draw the conclusion from each study. Therefore, this article has summarized the general conclusion within the domain of thermal comfort. The earlier work based on heat balancing of thermal environment was founded by P. O. Fanger in 1970 in Denmark. Since then the research especially on adaptive thermal comfort become endless process. Many eminent scientists like K. C. Parsons, M. Humphreys, F. Nicol, S Roaf, R. D. Dear and others have made tremendous efforts towards the research progress on thermal comfort. They initiated research by conducting experiments on subjects inside the climate chambers (de Dear et al., 2013).

Later, it progressed to field investigations for finding actual requirements of thermal comfort in commercial and residential buildings located in different climates. Subject's thermal comfort varies with climatic conditions, building typology, individual health and local adaptation. For this reason, these scientists have encouraged the global researchers to work upon the intricacies linked with comfort situation of the space subjects dwell in. Over the last decades, a paradigm shift in heat balance models towards adaptive thermal comfort models has happened. All adaptive thermal comfort models are based on the general hypothesis stating that subjects in NV building are more adaptive and tolerant of high indoor temperature as compared to the subjects in fully AC buildings (Van Hoof and Hensen, 2007). Therefore, the former can attain thermal comfort over a wide range of indoor temperatures. Further, the noticeable air movement in building has revamped research on thermal comfort in past decades. Earlier the perceptible air movement was negatively considered in terms of draft and 
nuisance; however, in present research, the positive hedonic facet of air movement such as thermal delight, aerodynamic pleasure and aesthetics of air are very commonly used (de Dear et al., 2013). The revised version of thermal comfort standards has also included the concept of elevated air velocity attributed towards offsetting higher air temperature in indoor space (ISO, 2005).

However, the earlier versions of standards never permitted it without air control requirement of individual subject. This shows that there has been considerable understanding of occupant interaction with building attributes particularly used for ventilation effects (Aynsley, 2008, 2005; Cândido et al., 2010; Zhai et al., 2019; Kabanshi et al., 2019). The credits for personal control rendering towards fulfilment of individual comfort requirements have been included in IEQ sections of many rating tools on building sustainability. Recent technological advancements in HVAC units like radiant cooling and chilled beams have not only improved the human thermal comfort but also the energy efficiency in buildings (Kim et al., 2019; Zhao et al. 2019). The MM buildings having more occupants' expectations through increased exposures impacting occupants' thermal perceptions have received special attention from the research community. As discussed earlier, thermal comfort studies have been broadly classified into two classes i.e. climate chamber studies and actual field studies (de Dear et al., 2013). The climate chamber based studies have better environmental control and internally valid research designs. Field studies on the other hand have benefits of large sample size and improved external validity.

Some recent studies (Wang et al., 2019; Zamani et al., 2019) have not used either of these approaches and used comfort simulation for producing climatic data useful in the development of thermal comfort model. The outputs of simulation model are also validated with real comfort assessment made through climate chamber and field studies (Zamani et al., 2019). Furthermore, it is obvious from the existing literature that the thermal comfort standards and approaches widely adopted by the western countries are being blindly used in Indian context, irrespective of its myriad of environment conditions, building construction practices and geographical aspects. This led to apprehension over the actual thermal comfort requirements of Indian subjects and hence, attributed to poor building energy performance as whole. Some studies like Sharma and Ali (1986) initiated the research on thermal comfort by developing TSI. Since then there has been considerable amount of research which needs to be propelled 
more through local field studies to identify the actual comfort and energy needs in Indian buildings.

\section{Climate of India}

India has very large and distinctive climatic zones varying from region to region, in fine terms it is defined that, it is the regular weather or statically description in relation with the mean and variability of relevant quantities over a period of time like months to thousands of years. In India, the NBC has classified five climatic zones namely, hot and dry, warm and humid, composite, temperate and cold. Details of each climatic zone are given as follows (NBC, 2016):

A. Hot and dry: This climate zone exists in the central and western parts of India such as Rajasthan, Gujarat and Maharashtra. The mean monthly temperature and relative humidity remains about $30^{\circ} \mathrm{C}$ and $55 \%$, respectively. These regions have high solar radiations and hot wind movements attributed towards high variations in diurnal temperature. Hot and dry regions have very little precipitation and a very short winter season. In these areas, the buildings are constructed of bricks, stones, cement and steel. Flat roofing is generally constructed of sandstone slabs and steel girders. The geographical distribution of hot and dry climate in India is presented in Figure 1.

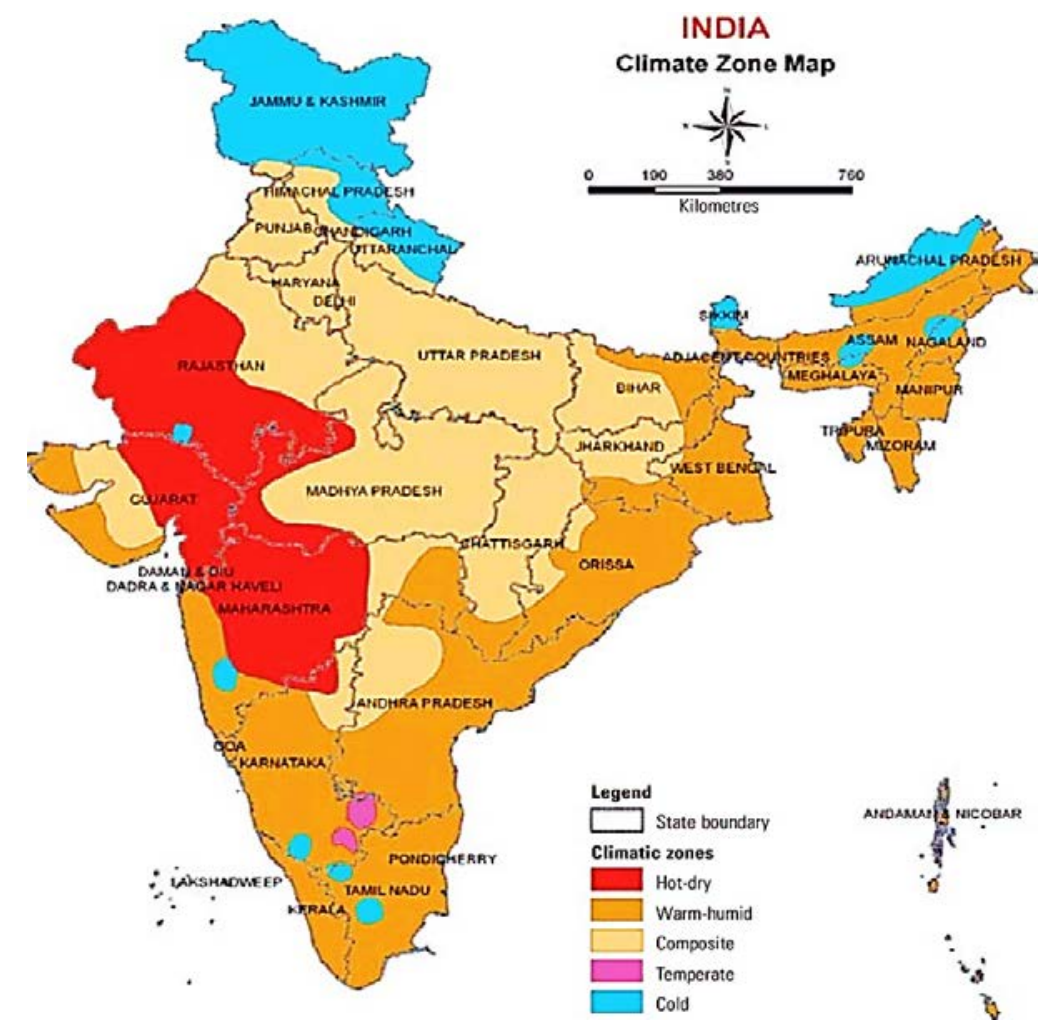

Figure 1. Geographical distribution of climatic zones in India (NBC, 2016). 
B. Warm and humid: It covers the costal parts of the country such as Mumbai, Kerala, Tamil Nadu, Goa, Orissa and West Bengal. These regions have high humidity and strong sun with heavy rainfall. Temperature in summer swings around $30-35^{\circ} \mathrm{C}$ and the relative humidity of $70 \%$ or above prevails during the hottest month of the year. The precipitation level is also high about $1200 \mathrm{~mm}$ per year. High humidity and diurnal variations in temperature along with steady air movement leads to greater thermal discomfort. The buildings constructed in these areas are generally having large openings for flow of air, rendering towards offsetting the high temperature conditions. In Orissa, the rural habitat is mostly built with unsterilized earth, stones and tiled roofs. Also, the bamboo and industrial wastes (like fly ash and furnace slag) are widely used in construction of buildings.

C. Composite: This climate lies in most of the parts of India such as East Rajasthan, Delhi, Uttar Pradesh, Madhya Pradesh, Haryana, Punjab, Bihar and Hyderabad. Temperature can hit up to $43^{\circ} \mathrm{C}$ in the summer season with heavy solar radiation and deep down to $10^{\circ} \mathrm{C}$ in winter season. Whereas the humidity level in summer swings between 10 to $25 \%$ and in winter, it varies from 55 to $95 \%$. The precipitation level also varies between 500 to $1300 \mathrm{~mm}$ per year. The composite climate covers most of the seasons as it has hot and dry climate, followed by monsoon which progressively ends to comfort autumn and then short spring with the cloudy and sunny periods. Generally, the construction materials used in buildings under this region are brick, mud, concrete, RCC and tiles. Thermal environment in these buildings depends on the orientation of buildings, landslides and water ponds for evaporative cooling.

D. Temperate: This climate generally remains comfortable throughout the year and found in Pune and Bangalore located on hilly or high-plateau regions with rich vegetation. Temperate climate has mild to warm summer and cool winters. The temperature conditions are neither too hot nor too cold because the solar radiation is more or less the same around the year. In summer, the temperature and humidity level varies from $30^{\circ} \mathrm{C}$ to $34^{\circ} \mathrm{C}$ and $20 \%$ to $55 \%$, respectively. Whereas in winter, the temperature varies from $27^{\circ} \mathrm{C}$ to $33^{\circ} \mathrm{C}$ and humidity of air remains relatively low. The precipitation level is around $1000 \mathrm{~mm}$ per year and winds are generally high during summer time. Building designers reduce heat gain by providing shading, climate responsive shape of building and reducing surface area through orientation. Whereas 
the ventilation through windows and courtyards is also encouraged to promote heat loss to restore thermal comfort and improve building energy performance.

E. Cold: This climate run into long winter and short summer and experiences in Jammu \& Kashmir, Himachal Pradesh and cities like Shimla, Shillong and Srinagar. The temperature in summer remains around $17^{\circ} \mathrm{C}$ to $25^{\circ} \mathrm{C}$ and can dip down to $-3^{\circ} \mathrm{C}$ to $8^{\circ} \mathrm{C}$ in winters. Humidity level in these places is generally high and can vary from $70 \%$ to $80 \%$. The precipitation level is about $1000 \mathrm{~mm}$ per year and the rainfall can be experienced throughout the year and heavy snow particularly in winter. Solar radiation is high in summer with high percentage of direct radiation and low in winter with high percentage of diffused radiation. Buildings in cold regions are designed to control heat loss through insulation and promoted for heat gain by trapping solar radiation. Vernacular architecture based on timber, soil and stone is generally found in the areas. Further, the mean monthly temperature and relative humidity obtained for different climatic zones are given in Table 1.

Table 1. Mean monthly temperature and relative humidity for different climates (NBC, 2016).

\begin{tabular}{|c|c|c|}
\hline Climate Zone & Mean monthly temperature & Mean monthly relative humidity \\
\hline Hot and dry & $>30$ & $<55$ \\
\hline Warm and humid & $<30$ & $>55$ \\
\hline Temperate & $25-30$ & $<75$ \\
\hline Cold & $<25$ & All values \\
\hline Composite & When six months or more do not fall in any of the within categories \\
\hline
\end{tabular}

\section{Literature search method}

This method involves the identification of study topics using the appropriate keywords related to "thermal comfort in residential buildings of India" at different electronic databases (such as Google scholar, ScienceDirect, Scopus etc.). The search for extracting the studies relevant to the objective of this review was made from April 2018 to August 2019. The Boolean operators using logical combination ("thermal comfort" AND "India”) OR ("thermal comfort" AND "Indian residential buildings") OR ("thermal comfort" AND "Indian dwellings") OR ("thermal comfort" AND "Indian subjects") were used to identify studies specific to this review. Most frequently words used in this review paper are visualised through word cloud as shown in Figure 2. 


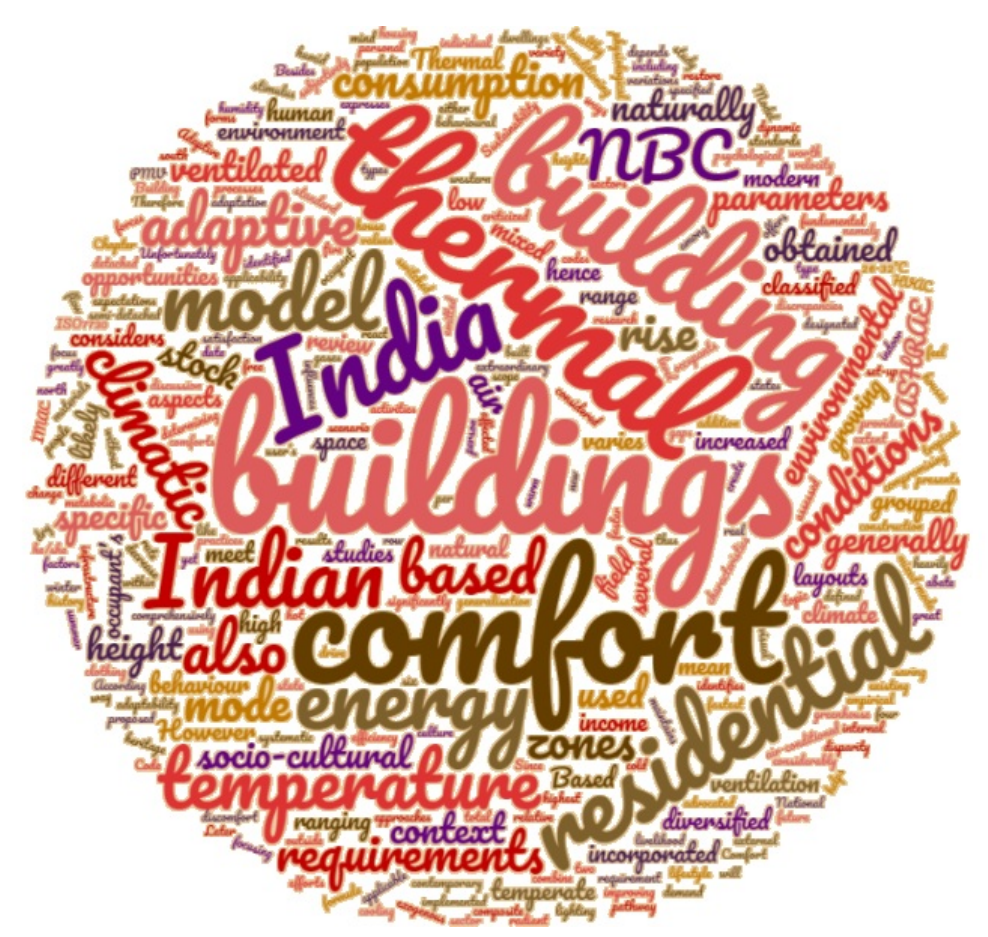

Figure 2. Word cloud depicting most frequently words.

The search was also made using the 'reference by reference' approach in which the reference sections of selected studies were focused to identify the required literature. However, the gray literature in the form of anecdote papers, discussion papers, editorial and presentations were discarded in this particular review. Only the peer-reviewed papers published in English language and relevant to the objective of review paper were considered. Some standards and works having relevance in Indian perspectives have also been referred for setting up the context. Therefore, the total numbers of studies found on thermal comfort in Indian residential buildings are 30 including one review paper (Mishra and Ramgopal, 2013) on thermal comfort field studies in different buildings typologies located worldwide. The identified papers are mostly field studies comprising both subjective and objective measurements of indoor and outdoor thermal environments. Details of these papers are given in Table 2 (refer Appendix). The year wise publications on thermal comfort specific to Indian residential buildings are shown in Figure 3. The highest no. of studies (09) have been published in year 2010 being mostly contributed (04) by Indraganti (Indraganti and Rao 2010; Indraganti, 2010a, 2010b, 2010c) in NV residential apartments located in Hyderabad under composite climate. Following this, the significant no. of studies (08) has been published by various researchers (Thapa et al., 2017; Singh and Chani, 2017; Netam et al., 2017; Kumar and Dibakar, 2017; Subramanian et al., 2017; Ponni and Baskar, 2017; Sthapak and Bandyopadhyay, 2017; Jaboyedoff et al., 2017) in year 2017. In other years, 
a very few thermal comfort studies have been performed which reflects that the thermal comfort studies in Indian dwellings are scant, scattered and unorganised.

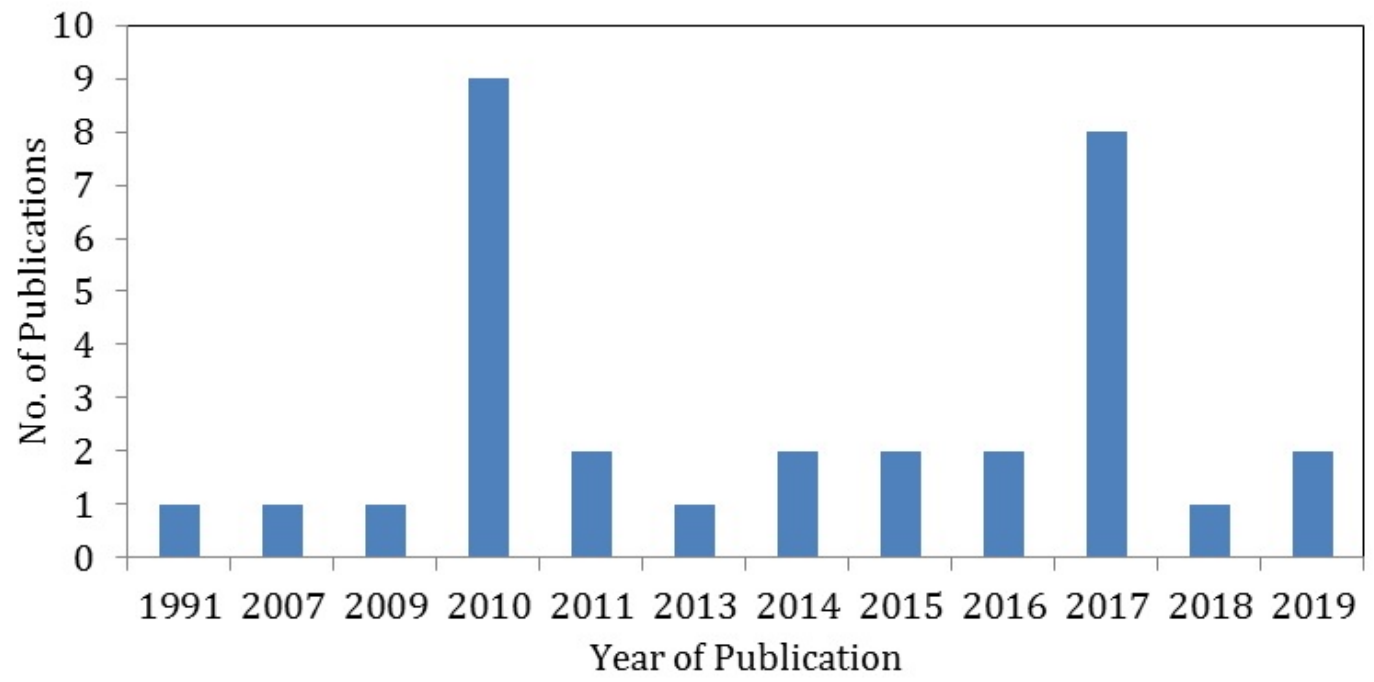

Figure 3. Year wise publications on thermal comfort specific to Indian residential buildings.

Details of top publication sources and their contribution to the present review are depicted in Figure 4. Top three journals including the peer-reviewed conferences contributed to $46 \%$ of the selected studies with Elsevier journals of Building and Environment, Energy and Buildings and Sage journal of Indoor and Built Environment being the specific journals responsible for the research development on thermal comfort in Indian dwellings. Three papers are from peer-reviewed conferences such as Windsor, Inspire and International Conference on Advances in Energy Research.

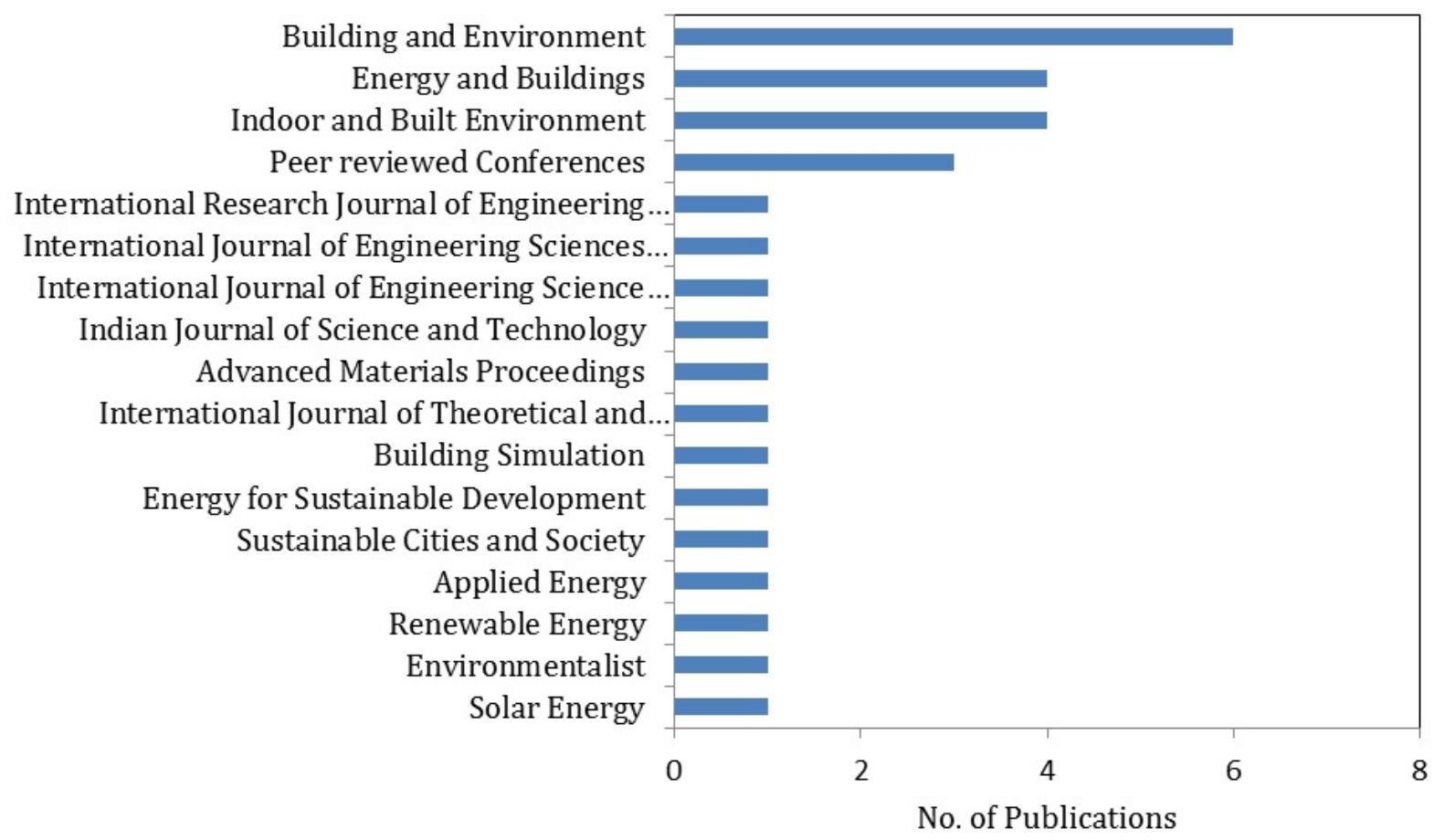

Figure 4. Publication sources and their contribution in the selected studies. 


\section{Thermal comfort methods and parameters used by Indian researchers}

The ASHRAE 55 (ASHRAE, 2004) and ISO7730 (ISO, 2005) standards are widely adopted for examining thermal environment in dwellings and determine the comfort levels of occupants at certain level of clothing and metabolic activities. The ASHRAE 55, in addition to the PMV-PPD approach, also partially considers the adaptive behaviour of occupants for examining the acceptable conditions of thermal comfort particularly in NV spaces. Besides, the ISO7730 proposes the PMV-PPD method for determining the indoor thermal comfort in buildings (ASHRAE, 2004; ISO, 2005). Both these standards are commonly adopted in thermal comfort field studies specific to Indian dwellings. Sharma and Ali (1986) also developed TSI model for hot-dry and warm-humid climates in India. The conditions of thermal comfort (i.e. temperature of $25-30^{\circ} \mathrm{C}$, humidity of 30 $70 \%$ and airspeed of $0-2 \mathrm{~m} / \mathrm{s}$ ) recommended by NBC (2005) are also based on TSI study. The higher range $\left(30-34^{\circ} \mathrm{C}\right)$ of air temperature can be offset with elevated airspeed of $1.5 \mathrm{~m} / \mathrm{s}$.

Rajasekar and Ramachandraiah (2010) determined the acceptable range (31$26.8^{\circ} \mathrm{C}$ ) of comfort temperature and a thermo-neutral temperature of $28.8^{\circ} \mathrm{C}$ in terms of TSI. Thus, the occupants from NV residential buildings showed the wide range of thermal acceptability than described in ASHRAE and ISO standards. Mostly field studies have adopted ASHRAE class-II protocol that requires environmental measurement probes to be placed at $1.0 \mathrm{~m}$ above the floor and nearest to the sitting respondent. Major six thermal comfort parameters i.e. four environmental (RAT, GT, RH and air velocity) and two personal parameters (such as clothing insulation and metabolic activity) are measured (Indraganti, 2011; Indraganti and Rao 2010; Indraganti, 2010a, 2010b, 2010c; Singh et al., 2010a, 2010b). The simultaneous measurements of subjective (i.e. occupant's sensation and preference) and objective information (i.e. indoor and outdoor environmental parameters) are common practice adopted for detailed evaluation of indoor thermal conditions in buildings. However, the PMV-PPD model ignores the sociocultural aspects and contextual dimensions of comfort. Studies based on these models deny all processes of thermal adaptation.

Further, the methods commonly used for obtaining the findings (such as the comfort temperature, relationship between thermal comfort parameters) are Linear Regression (Indraganti 2011; Indraganti and Rao 2010; Indraganti, 2010a; Kumar et al., 2016a, 2016b; Singh and Chani, 2018; Thapa et al., 2017; Singh et al., 2010b; 2011), 
Multiple Regression (Singh et al., 2010a, 2015), Polygon regression (Indraganti, 2010b, 2010c), Least square method (Singh et al. 2011), Polynomial regression (Thapa et al., 2019; Singh et al. 2011) and Griffiths Method (Kumar et al., 2016a, 2016b; Thapa et al., 2019). Of these, the linear regression and Griffith's method are used to derive thermal neutrality. Some studies (Singh et al. 2011, 2010a, 2010b) have only used objective measurements of indoor environmental parameters (temperature, humidity and indoor lighting level) and developed formulae using regression models for predicting indoor thermal conditions of house. Subramanian et al. (2017) examined thermal comfort of dwelling constructed with solar passive design based on the objective measurements of temperature and humidity inside the built space.

Ponni and Baskar (2017) experimentally studied the thermal performance of high-rise building during summer season. In addition to indoor temperature, the temperature of the inside roof and walls were measured. Most of the studies have considered ambient data from locally installed weather data. Singh et al. (2011) calculated adaptive coefficients (expressing the level of adaptation) for different climatic zones using least square method. Kapoor and Tegar (2018) determined the score of various elements of indoor environment (i.e. thermal comfort, air quality, lighting and acoustic) using five star rating scales in residential buildings of Bhopal. Praseeda et al. (2014) used dynamic simulation to study the effect of material transition and thermal comfort models (i.e. ASHRAE and TSI) on energy performance of vernacular buildings. Jaboyedoff et al. (2017) performed simulation work to analyse the reduction in heat gain through energy-efficient envelope and ventilation strategies for revamping thermal comfort in high-rise residential buildings located under multiple climates. Shastry et al. (2014) developed building simulation model using DesignBuilder for investigating the thermal comfort characteristics of vernacular building and validated the results in good agreement with real-time data.

Netam et al. (2017) used CFD model for analysis of thermal performance of residential house and identified temperature distribution inside it and suggested design modification to moderate the indoor thermal condition. Kumar and Dibaka (2017) developed numerical modelling for comparative thermal comfort assessment in buildings using insulation and PCMs under multiple climatic conditions. Thermal comfort studies by Indraganti (Indraganti, 2011; Indraganti and Rao 2010; Indraganti, 2010a, 2010b, 2010c) considered socio-cultural parameters (such as economic group) 
and behavioural controls (such as window opening, use of fan and lights etc.) in addition to the above mentioned six thermal comfort parameters. Whereas Singh et al. (2009, 2010a, 2010b, 2011, 2015) in his studies for NV residential buildings considered various demographic (i.e. gender, age), context (i.e. building design and functionality), cognition (i.e. attitude, preference and expectations) and indoor environmental factors. The details of methods, parameters and instrumentation used by thermal comfort studies specific to Indian residential buildings are given in Table 3 (refer appendix).

\section{Thermal comfort studies in Indian dwellings}

Research on thermal comfort particularly in Indian dwellings has gained momentum after year 2010. Various researchers have performed field studies and simulation work on residential thermal comfort in different geographical locations and climates. These studies are grouped based on climatic zones, as given follows:

\subsection{Thermal comfort studies under hot and dry climate}

Netam et al. (2017) examined thermal comfort in LIG houses of Chhattisgarh. The design standards set by Chhattisgarh housing board authority were insufficient in fulfilling the requirements of thermal comfort in building constructed under extreme climatic conditions. Temperature distribution of indoor spaces was estimated using CFD modelling and based on the analysis, different thermal zones were suggested for improving the building designs. Udaykumar et al. (2015) investigated thermal comfort performance of NV residential apartments in Ahmedabad through real-time monitoring and the data thus obtained was used for validation of simulation results. The comfort temperature determined in the study was significantly different than the national and international standards i.e. ePMV and TSI. Compared to TSI, the ePMV and comfort temperature indices estimated higher heat discomfort of $50 \%$ and $62 \%$, respectively during summer. While in winter, the TSI and comfort temperature indices expressed higher cold discomfort of $60 \%$ and $77 \%$, respectively. The ambient comfort range of 25 $31^{\circ} \mathrm{C}$ and $21.5-27^{\circ} \mathrm{C}$ was obtained for summer and winter seasons, respectively.

\subsection{Thermal comfort studies under warm-humid climate}

Dili et al. (2010) quantitatively analysed the effect of various factors (i.e. temperature, humidity and air velocity) on thermal comfort in traditional residential buildings of Kerala using questionnaire survey conducted for summer, monsoon and winter seasons. The bedroom where occupants spent most time and performed more 
adaptive control actions was mainly focused. Building designs, construction practices and materials were found to play the key role in attaining the acceptable comfort environment. Rajasekar and Ramachandraiah (2010) evaluated adaptive thermal comfort in NV residential apartments. Various demographic factors (like age, economic status), thermal expectation and occupant's thermal history were playing vital role in estimating the thermal comfort perceptions. A strong relationship between thermal sensation and running mean outdoor temperature was obtained (refer Figure 5) indicating that the thermal response of subjects' substantially depends on the past thermal history. Comfort temperature $\left(26.9-31.0^{\circ} \mathrm{C}\right)$ at neutral temperature of $28.8^{\circ} \mathrm{C}$ was obtained to be greater than the limits prescribed by traditional comfort standards.

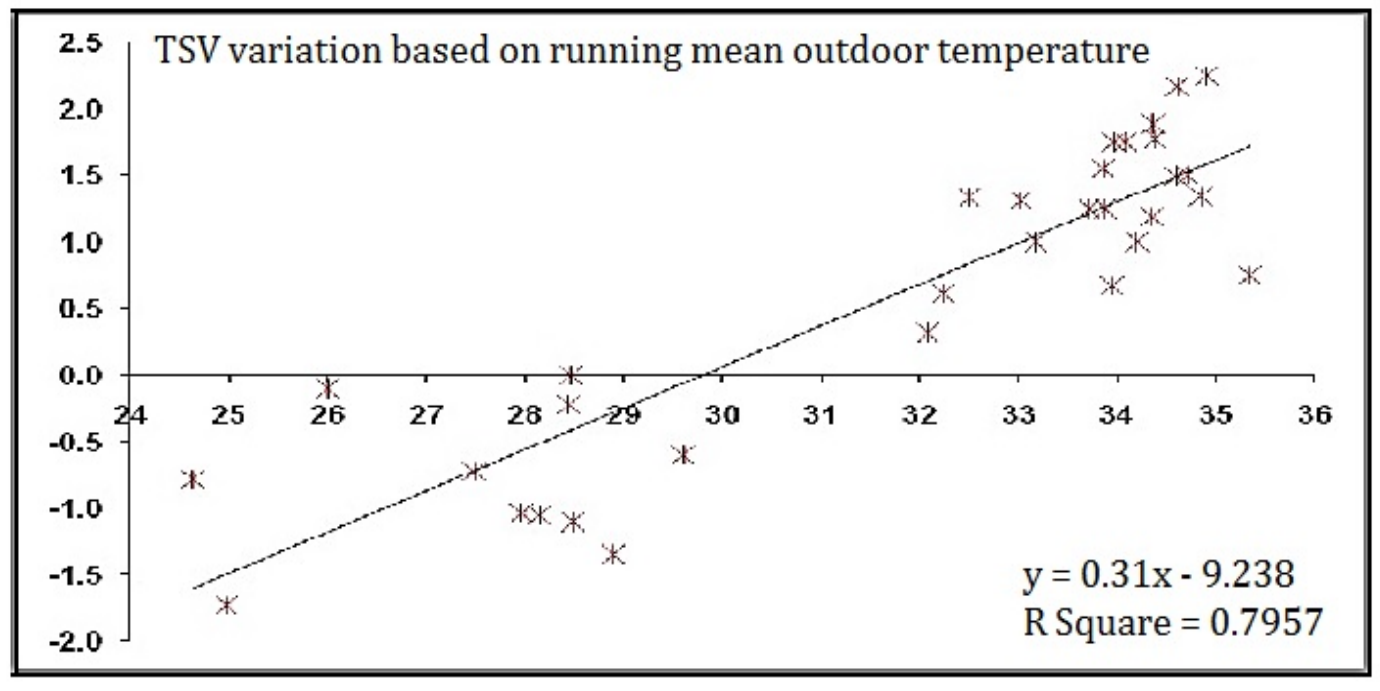

Figure 5. Relationship between TSV and running mean outdoor temperature (Rajasekar and Ramachandraiah 2010).

Shastry et al. (2014) simulated the effect of passive solar elements on indoor thermal environment of vernacular dwellings located in Sugganahalli. The transition of age-old building designs into modern building design was studied in terms of bio-climatic and climatic responses. The increase in average indoor temperature of $7-10^{\circ} \mathrm{C}$ was reported in summer seasons in modern transitions. However, the modern building designs were effective in attainting thermal comfort using air-conditioning. Praseeda et al. (2014) adopted two thermal comfort models (i.e. ASHRAE's comfort model (ASHRAE 55, 2004) and Sharma and Ali (1986)) to study their impacts on operational energy in NV vernacular building in Sugganahalli. The ASHRAE standards underestimated the operational energy for residential buildings under warm-humid climate and overestimated the same for residential buildings under hot-dry climate. The impact of material transition of walls on embodied energy was also investigated. Replacing rubble 
stone masonry with burnt clay brick masonry and stabilised soil block masonry reported the increase in embodied energy by $870 \%$ and $120 \%$, respectively.

Subramanian et al. (2017) analysed thermal comfort in solar passive housing located in Thanjavur. Various solar passive architecture techniques (such as courtyard design, high ceiling roof, light colors painting, etc.) were incorporated in the buildings. Compared to contemporary building, the temperature of these buildings was reduced by $2-3^{\circ} \mathrm{C}$ in summer season. Thus, the indoor comfort temperature obtained was 25 $30^{\circ} \mathrm{C}$ (complying with temperature range given in ASHRAE and TSI thermal comfort standards) in summer conditions. Ponni and Baskar (2017) studied thermal performance of multi-storey residential buildings in Chidambaram. The indoor temperature was observed to be nearly constant even if outside temperature was varying. A significant temperature variation in roof, walls and indoor spaces was observed among different floors. The indoor temperature of all the three floors was observed to be decreased gradually from top floor to ground floor. Sthapak and Bandyopadhyay (2017) examined the role of vernacular houses in achieving the required air flow for acceptable comfort levels in living spaces. Air circulation was found to be depending on proportions of surrounding walls and opening of windows in surrounding rooms. Construction of courtyard was useful in prevailing the climatic conditions and improving thermal comfort without use of air-conditioning consuming significant amount of energy.

\subsection{Thermal comfort studies under composite climate}

Garg (1991) determined thermal environment of building, index quantifying discomfort and degree of discomfort. Various passive options that reduced thermal discomfort up to $66.7 \%$ in buildings during summer season were identified. Use of whitewash walls and roof, wall having $120 \mathrm{~mm}$ thick bricks and $230 \mathrm{~mm}$ mud layer on inner surface and grouping building envelopes in horizontal direction along east-west axis were found to be the most effective passive option for controlling indoor environment in residential buildings. Sharma and Tiwari (2007) used occupant's thermal preferences to develop an adaptive thermal comfort model for composite climatic conditions. In summer, the higher air movement was found to be the primarily requirement to offset high temperature conditions. The level of discomfort obtained for higher indoor temperature is shown in Figure 6. 


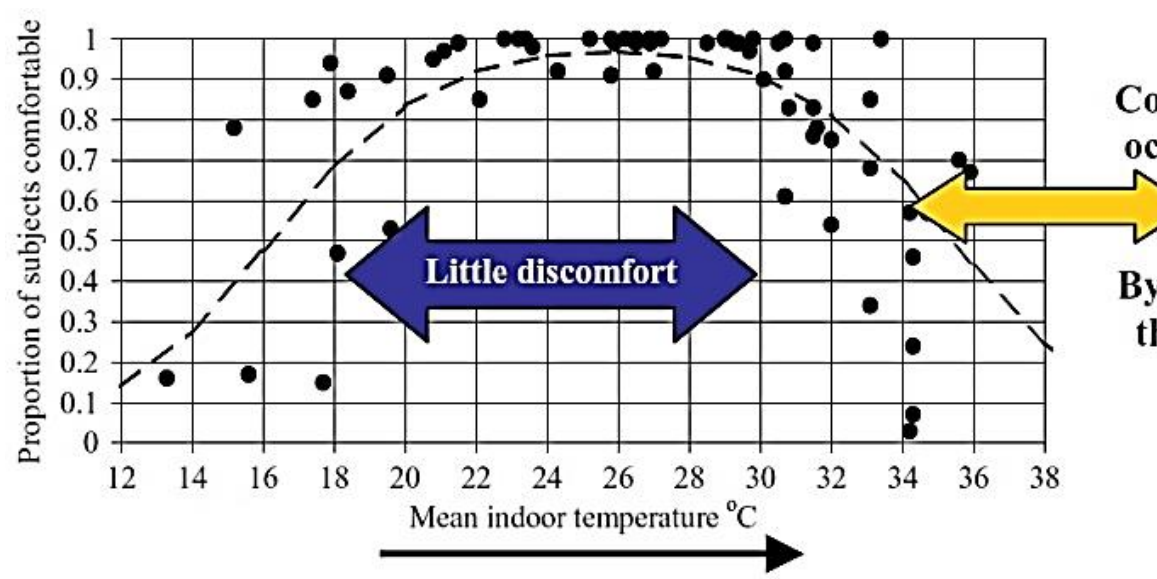

Comfort is achieved by the occupants adapting to the $>$ building Or By the occupants adapting the building to suit them

Figure 6. Level of discomfort obtained for higher indoor temperature (Sharma and Tiwari, 2007).

Indraganti and Rao (2010) performed field study to examine the impact of age, income and gender on thermal environment in residential apartments in Hyderabad. Thermal requirements of female, old subjects and owner subjects were reported to be higher. The subject's income level showed notable effect on thermal sensation, preference, acceptance and neutrality. The comfort range of temperature obtained for the lower income group was $27.3-33.1^{\circ} \mathrm{C}$. Indraganti (2010a) analysed the adaptation characteristics of building occupant's in NV buildings for summer season of Hyderabad. The use of fan, cooler and air-conditioning was increased with increase in temperature and depends on the occupant's attitude and economic affordability. The comfort band of temperature $\left(26.0-32.5^{\circ} \mathrm{C}\right)$ obtained by the study was higher than the Indian Building codes. Further, the thermal tolerance was limited in subjects often use AC's and thus caused thermal indulgence.

Indraganti (2010b) evaluated the occupant's adaptive use of natural ventilation for thermal comfort in residential apartments in Hyderabad. Adaptive behavior of occupants was observed to be significantly influenced by several non-thermal factors (like age, attitude, operation, maintenance etc.). The comfort range of temperature $\left(26.0-32.5^{\circ} \mathrm{C}\right)$ obtained for building occupants was afar than the comfort range (23.0$26.0^{\circ} \mathrm{C}$ ) recommended by Indian codes. Indraganti (2010c) performed field study to determine the natural temperature in residential buildings of Hyderabad. Neutral temperature obtained for the building occupants living at the top floor was found to be higher due to the fact that the adaptive opportunities (such as clothing, metabolism, windows, external doors and curtains) for those occupants were high. Neutral temperature and GT were found to be equal when mean TSV of the subjects were close to 0 . Finally, the neutral temperature for comfort temperature band of $23-32.45^{\circ} \mathrm{C}$ was 
$29.23^{\circ} \mathrm{C}$. The proportion of subjects responded within the comfort zone in different buildings and months of years are shown in Figure 7.

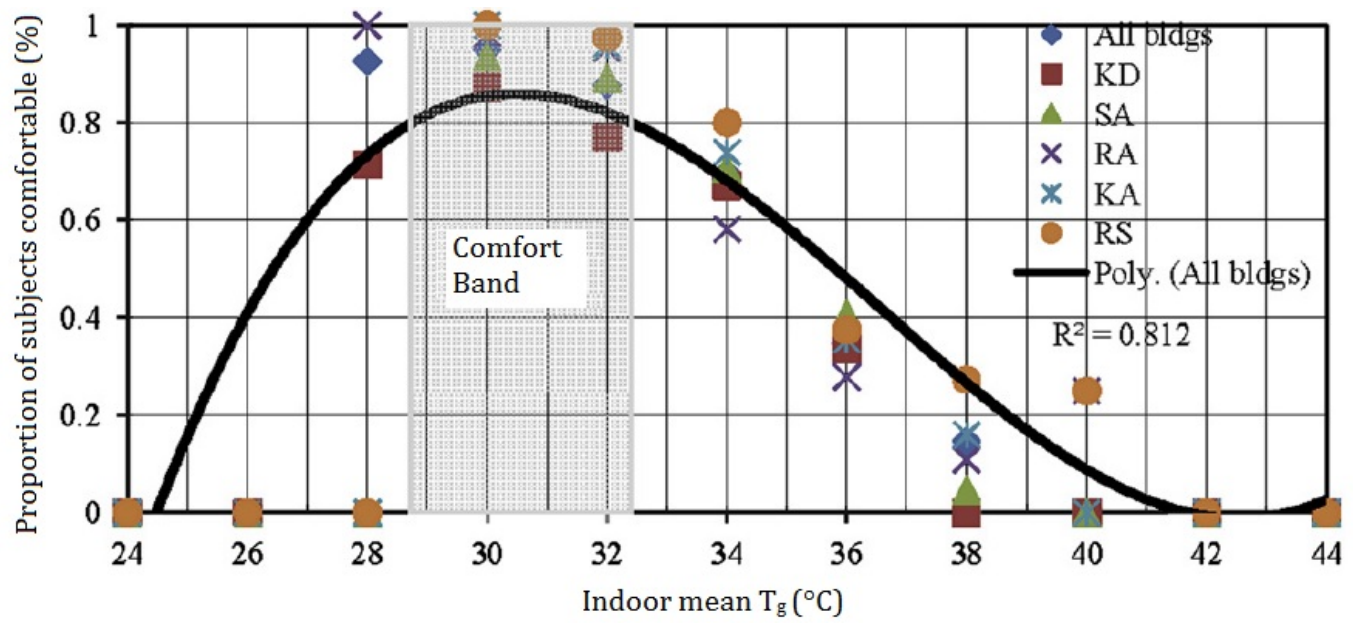

Figure 7. Proportion of subjects responded within the comfort zone in different buildings (Indraganti, 2010c).

Indraganti (2011) examined the occupant's adaptation methods for controlling the indoor environment. Though the use of fan, cooler and air-conditioner was increased with increase in temperature but these control actions was impended by different reasons (such as poor efficacy, economic affordability, noise and subject's attitude). Higher behavioural adaptation mostly limited in high economic group was observed during summer and monsoon seasons; however, in moderate environment, sitting is airy place and drinking cold water were very common. The comfort band of temperature $\left(26.0-32.5^{\circ} \mathrm{C}\right)$ obtained was higher than the Fanger's PMV model overestimating the actual sensation. Kumar et al. (2016a) investigated adaptive behavior of occupant's for acceptable comfort temperature in total 32 no. of $\mathrm{NV}$ buildings (14 office +18 residential). Different seasons, age categories, building types and clothing were considered while performing the thermal comfort field study. The comfort temperature of $30.6^{\circ} \mathrm{C}$ and $25.2^{\circ} \mathrm{C}$, clothing insulation of 0.3 clo and 0.8 clo and air velocity of $0.62 \mathrm{~m} / \mathrm{s}$ and $0.27 \mathrm{~m} / \mathrm{s}$ were obtained for summer and winter seasons, respectively. The mean air velocity measured for using window opening and fan for different seasons is shown in Figure 8. 


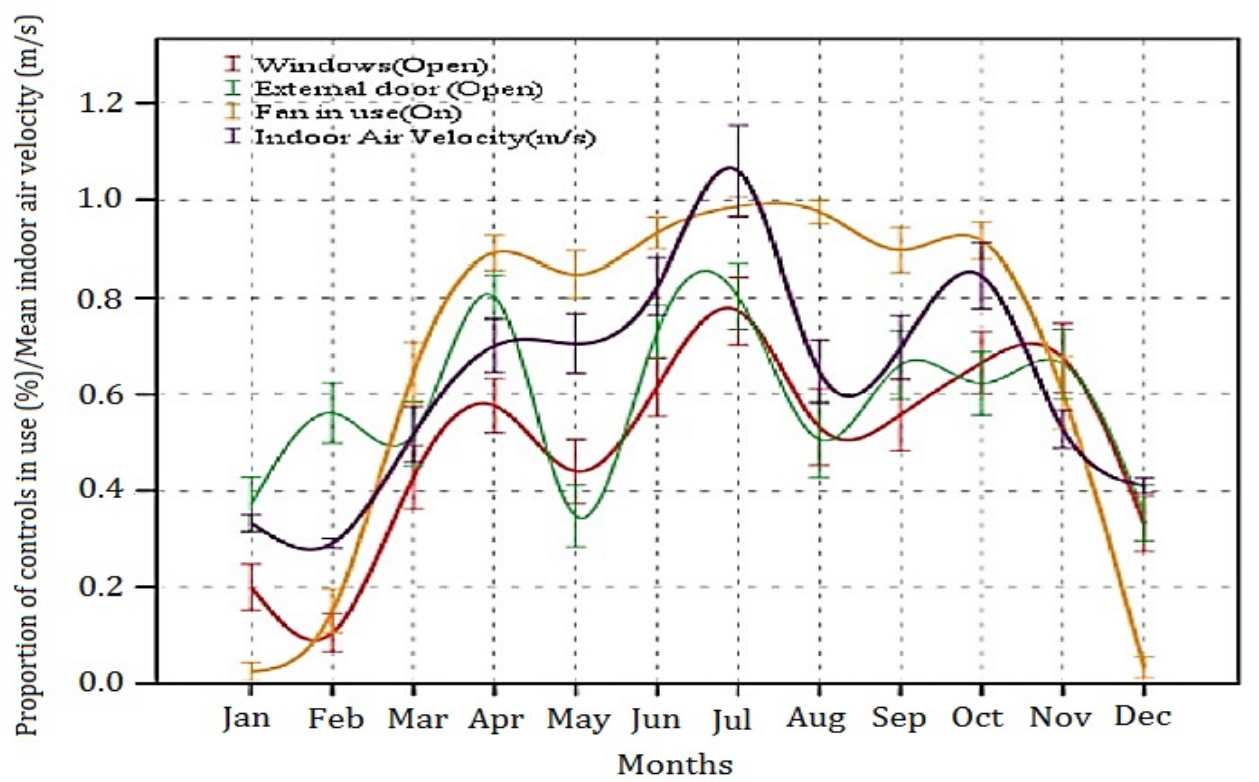

Figure 8. Use of controls and indoor air velocity in NV buildings (Kumar et al., 2016a).

Another study (Kumar et al., 2016b) by same author investigated comfort boundaries at different levels of air velocities (i.e. up to $0.2 \mathrm{~m} / \mathrm{s}, 0.2-0.5 \mathrm{~m} / \mathrm{s}$ and $0.5-1.5 \mathrm{~m} / \mathrm{s}$ ) by following ASHRAE 55 (ASHRAE, 2013) and ISO7730 (ISO, 2005) calculations used for determining offset in air temperature at elevated air velocities. The results thus obtained indicated that the subjects were comfortable at higher temperature conditions different from those suggested in international standards. At still air (up to $0.2 \mathrm{~m} / \mathrm{s}$ ), the subjects responded comfortable up to $32^{\circ} \mathrm{C}$ and for higher air velocity (up to $0.2 \mathrm{~m} / \mathrm{s}$ ), the subjects were comfortable even up to $35^{\circ} \mathrm{C}$ in $\mathrm{NV}$ buildings of India. Singh and Chani (2018) studied the effects of various factors (i.e. gender, age, season and subject's exposure to roof heat) on subject's thermal sensation in NV multi-storey apartments in Roorkee. Female subjects were more environment sensitive as compared to male subjects. Whereas the small range of comfort temperature and high thermal sensitivity was estimated for the elderly subjects. The neutral temperature of $26.1^{\circ} \mathrm{C}$ was calculated for the comfort band of $22.5-30.6^{\circ} \mathrm{C}$.

\subsection{Thermal comfort studies under cold climate}

Thapa et al. (2017) investigated the effect of elevation on requirements of thermal comfort in dwellings of north-east India. The significant variations in clothing insulation and parameters of thermal comfort were observed with difference in elevation and outdoor environment conditions. However, despite the substantial variations in climatic conditions, the subjects obtained thermal comfort via high 
adaptation (such as putting more clothing). The variation in comfort temperature with clothing insulation is shown in Figure 9.

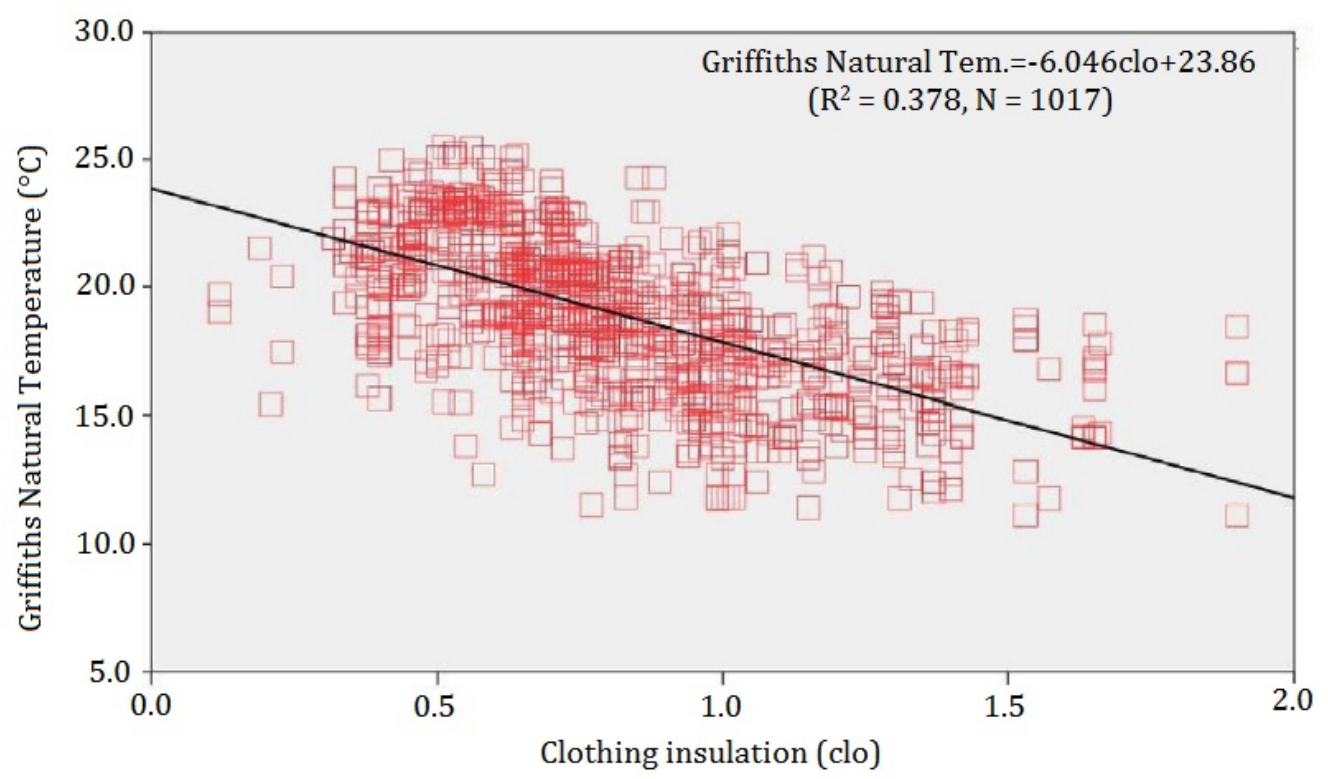

Figure 9. Variation in comfort temperature with clothing insulation (Thapa et al., 2017).

Thermal comfort field study recently carried out by same author (Thapa et al., 2019) proposed the new comfort zone for residential houses in Darjeeling. For temperature, the lower and upper limits were proposed to be $13.8^{\circ} \mathrm{C}$ and $20.6^{\circ} \mathrm{C}$, respectively while for humidity, it was obtained to be $20 \%$ and $90 \%$, respectively. The female occupants covering less clothing rendered high discomfort with higher comfort temperature. Moreover, the closeness of comfort temperature with indoor and outdoor environmental conditions indicated that the occupants were more adaptable to the environmental conditions.

\subsection{Thermal comfort studies under multiple climatic zones}

Singh et al. (2009) determined the association between bioclimatism, sociocultural set-up, economic status and sustainability for vernacular dwellings of northeast India. Based on the analysis, the functional diagrams of buildings satisfying the socio-economic and socio-cultural setup were drawn. However, more quantitative studies were required to study bioclimatism of buildings. Singh et al. (2010a) performed long term monitoring to develop thermal comfort modeling for predicting indoor temperature in vernacular houses of Tezpur and Cherrapunjee cities of NorthEast India. Various adaptive control actions (like window, ventilator, fan and clothing) were used to control the indoor environment. A good agreement between measured temperature and temperature obtained using the prediction formulae was reported. 
Singh et al. (2010b) studied thermal performance of vernacular dwellings under different climates of North-Eastern India. None of the house was found significantly comfortable during winter; however, they were sufficiently comfortable in pre-summer, summer and pre-winter periods. Instead of OT and MRT, the DBT was commonly used to represent comfort temperature. The comfort temperatures for Tezpur, Imphal and Cherrapunjee were found to be varying from 22.8 to $28.4^{\circ} \mathrm{C}, 21.1$ to $26.5^{\circ} \mathrm{C}$ and 19.0 to $24.3^{\circ} \mathrm{C}$, respectively for all seasons. Singh et al. (2011) developed the adaptive thermal comfort models for vernacular residential buildings under different climates of NorthEastern India. Based on PMV and AMV values, different adaptive coefficients were computed for various climatic zones (refer Figure 10) that expressed the level of adaptation for different climatic conditions and seasons.

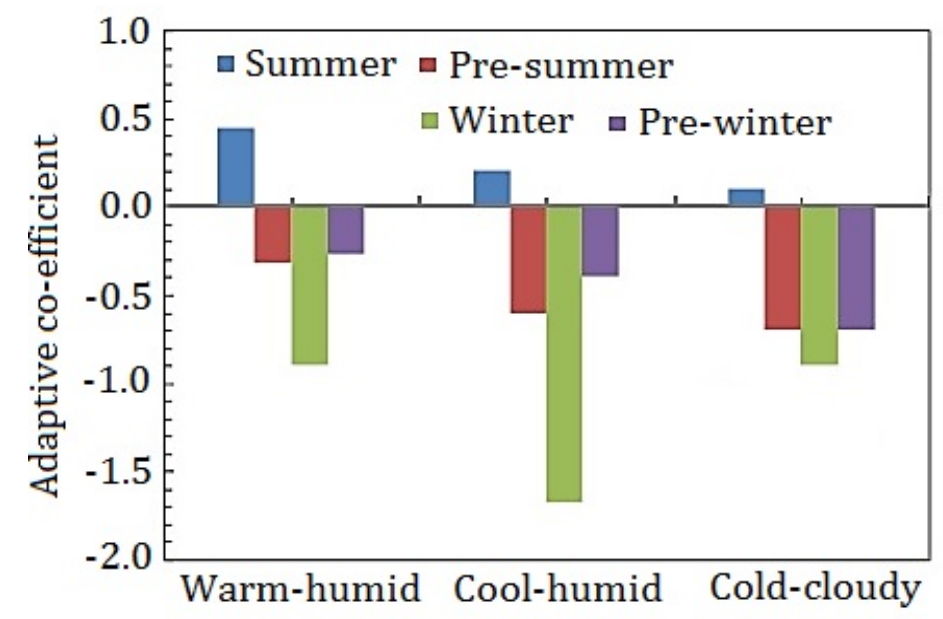

Figure 10. Adaptive coefficients computed for various climatic zones (Singh et al. 2011).

The positive adaptive coefficients indicate the cooler feeling than PMV and generally occur in summer season when indoor temperature was higher than comfort temperature. Whereas the negative adaptive coefficients indicates the less cold feeling than PMV and generally happens in winter months. The results thus obtained can be useful in examining the applicability of PMV model in NV buildings.

Singh et al. (2015) developed thermal comfort models based on local environment factors, behavioral control and socio-culture parameters. Neutral temperature obtained using regression models was compared with comfort temperature determined through comfort survey. Based on the analysis, it was concluded that the thermal comfort models cannot be generalized for all climates because of the fact that the comfort needs highly depends on the adaptation process, perception and socio-cultural factors. Kumar and Dibakar (2017) investigated thermal 
comfort in residential buildings for three scenarios (i.e. construction using brick wall and concrete roof, insulation over walls and roof and PCM over walls and roof) in three cities (i.e. Bhubaneswar, Jodhpur and Delhi) using energy simulation. For Bhubaneswar, the PCM based construction was reported better than insulation for improving the indoor environment. However, the use of PCM in Delhi and Jodhpur was comparable and not significant energy saver.

Jaboyedoff et al. (2017) estimated the energy use for cooling and ventilation applications in multi-storey residential buildings. Various strategies (such as appropriate shading of windows, insulation of walls and roof) related to building envelope and ventilation were recommended for reducing solar heat gain and improving the characteristics of thermal comfort in built space. The reduction in OT by $4-7^{\circ} \mathrm{C}$ was reported in buildings under different climatic zones of India. Kapoor and Tegar (2018) assessed factors of IEQ using subjective measurements in residential buildings of Bhopal. Thermal comfort was reported to be having the highest weightage of 3.7 followed by indoor air quality (3.5), lighting (2.8), acoustic (2.5) and visual comforts (2.4). Various passive options suggested for increasing comfort level were building orientation, use of light colour paint and electric appliances, creation of microclimate, prevention of infiltration and training of building professionals.

India is having the largest building stock of NV buildings and therefore, most of the studies are carried out in these buildings. The climate wise distribution of thermal comfort studies specific to Indian dwellings is shown in Figure 11.

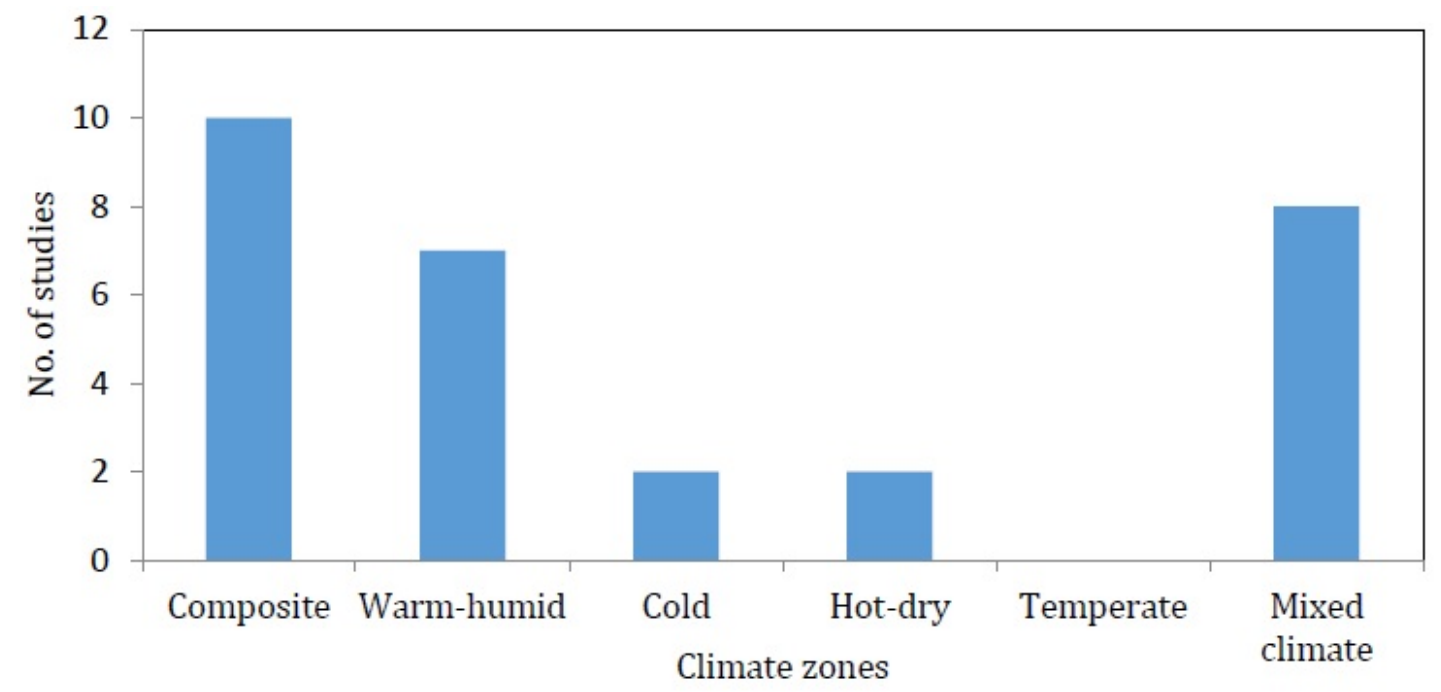

Figure 11. Climate wise distribution of thermal comfort studies.

Majority of these studies belongs to composite climate (ten), followed by warmhumid (seven) and a very few from cold (two) and hot-dry (two) climates. However, 
none of the studies are found from the temperate climate. This indicates that the thermal comfort studies in Indian residential buildings are scattered and unorganized. A total of five studies used simulation tool and three used experimental approach including numerical modelling to examine thermal comfort in residential buildings. The remaining are field studies that provide the general understanding about indoor thermal environment, outdoor climatic conditions, controlling factors and local adaptations in Indian perspectives. However, these studies have not discussed about the association between acceptable comfort conditions and occupant's working performance. Among total of 29 thermal comfort studies (excluding one review paper), eight studies investigated thermal comfort in residential buildings across multiple climatic zones. The geographical spread of buildings where thermal comfort studies were performed is depicted in Figure 12.

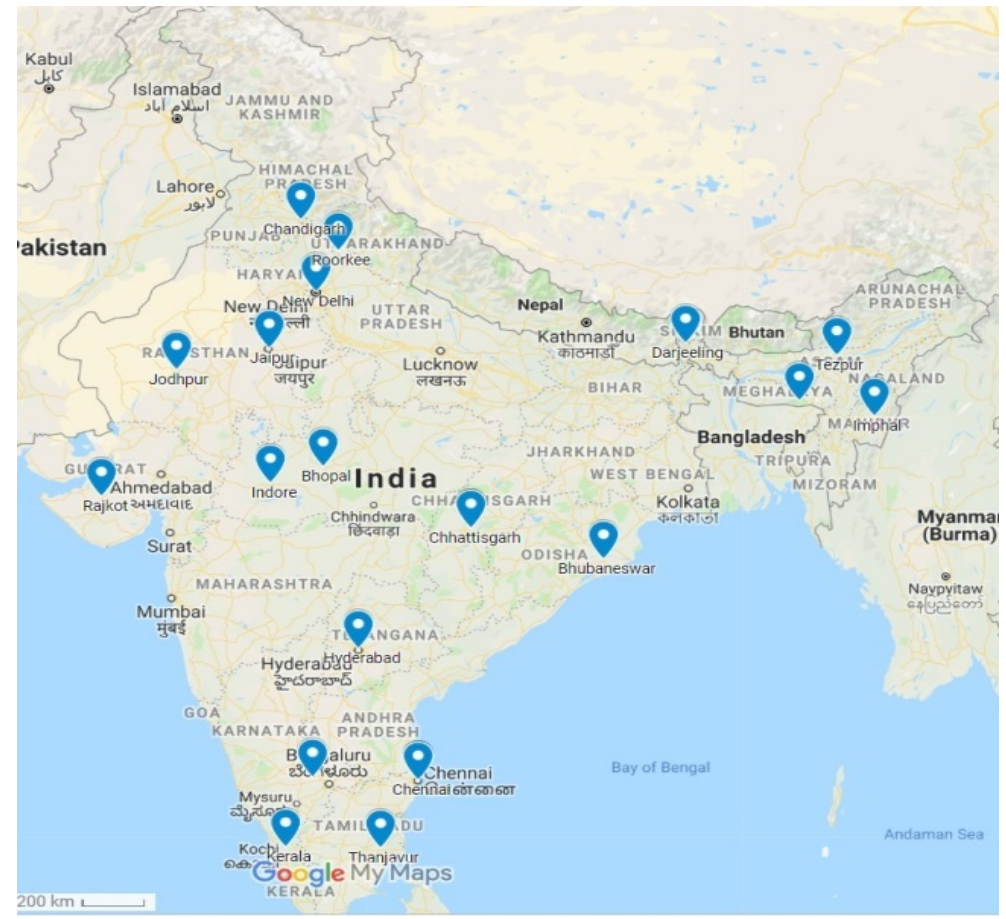

Figure 12. Geographical spread of thermal comfort studies specific to Indian dwellings.

Further, the wide range of comfort temperature obtained by various studies is way above the range prescribed by NBC which is in fact based on International thermal comfort standards. This shows that there is need of local thermal comfort standards for Indian dwellings. The region-specific adaptation and socio-cultural set-up are attributed to cause difference in thermal comfort requirements. Therefore, besides developing the empirical correlations, more local field studies are entailed to investigate the actual requirements of thermal comfort in dwellings. Details of studies on thermal comfort in Indian residential buildings are presented in Table 3 (refer Appendix). 


\section{Discussion of findings}

The present review explored the present state of research on thermal comfort specific to Indian dwellings, informed by numerous factors including occupant behaviour, region-specific climatic conditions and socio-cultural aspects. Most of the existing studies are relying on Fanger's PMV model (Fanger, 1970) and ASHRAE's adaptive model (ASHRAE, 2004) to study the state of thermal comfort in built environment. Adaptive model is usually applied to NV building while the PMV model is applied to air-conditioned buildings. The adaptive behaviour which is stochastic in nature is overlooked or partially considered in the existing thermal comfort studies. The straightforward use of Fanger's model can underestimate the human thermal adaptability to indoor environment up to 50\%. (Humphreys, 1992). This leads to inappropriate thermal design of building and excessive building energy consumption. The systematic discrepancies of global standards have been the question of debate among the scientific community worldwide. As a result of it, the actual state of thermal comfort is difficult to determine particularly in residential buildings having more adaptive ways, less predictive activities and large variations in thermal comfort requirements.

Only a few studies (Indraganti and Rao 2010; Indraganti, 2010a, 2010b, 2010c; Kumar et al., 2016a, 2016b; Thapa et al., 2017, 2019; Singh et al. 2011) provides the limited understanding about controlling factors, influence of outside environment and adaptation behaviour regarding control of indoor thermal environment in residential buildings. These studies have developed the adaptive thermal comfort equations for NV buildings which clearly imply the need of alternative options other than ASHRAE's adaptive comfort equations. Studies on thermal comfort in office and residential buildings have reported the wide range of comfort temperature which is way above the values recommended by global standards. Due to diversified climatic conditions and building construction practices, this comfort range is ineffective when compared with different studies (refer Figure 13). In NV buildings, the use of adaptive control actions (i.e. window and door opening, use of fan etc.) especially in summer season yield higher comfort temperature than that suggested by NBC (2005). Further, the use of airconditioning for acceptable thermal environment (as mentioned in International standards) can lead to high building energy consumption in India. However, such a wide comfort band reveals the potential of energy saving in Indian buildings. Comfort 
temperature range obtained by various studies specific to Indian residential building is depicted in Figure 13.

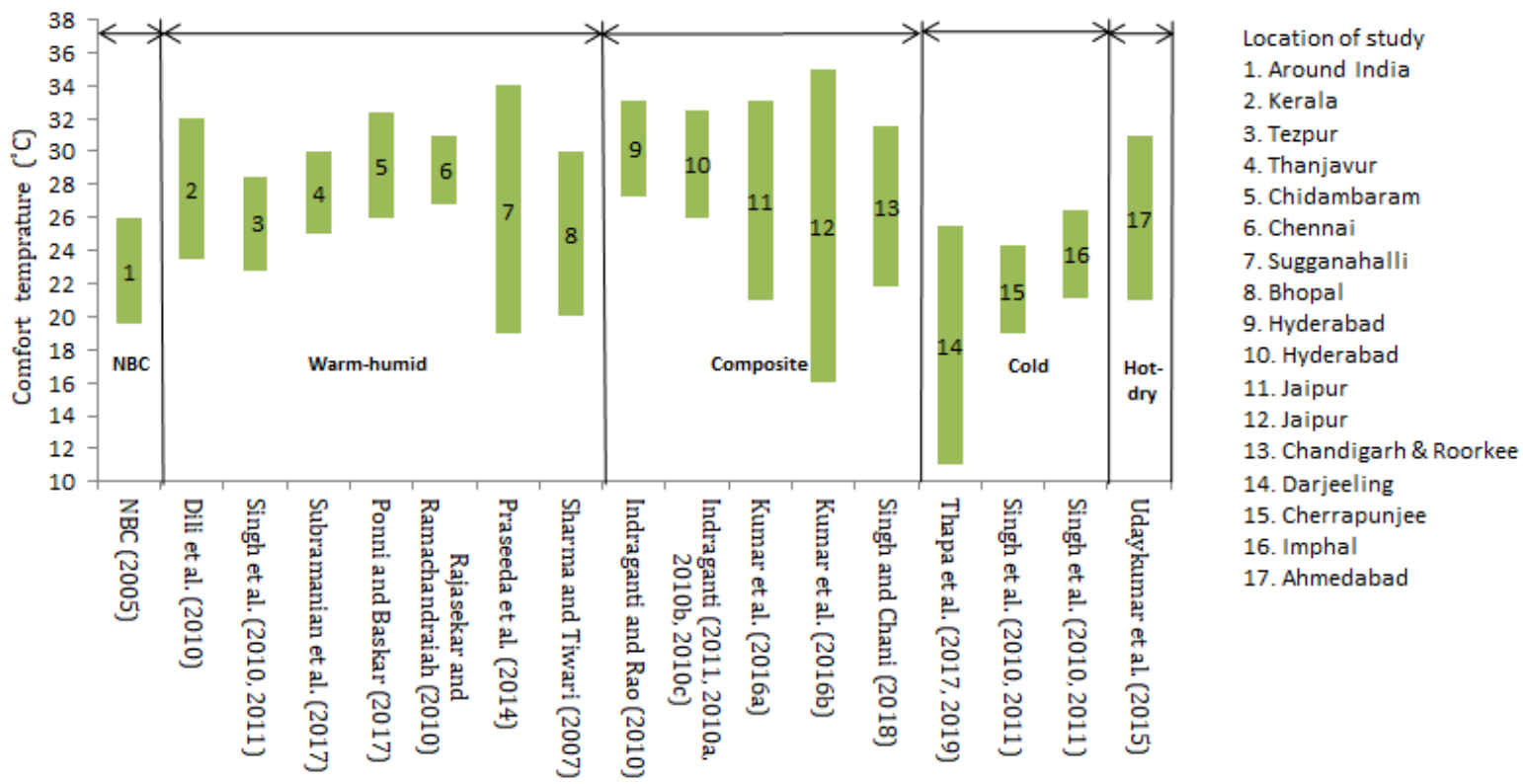

Figure 13. Comfort range obtained by different studies in Indian residential buildings.

The country-specific thermal comfort standards are required to be developed considering the socio-cultural set-up and thermal adaptation capacity of Indian subjects. The lack of code of conduct is also responsible for not having the local thermal comfort standard. Such guidelines can be helpful in providing the design and operation related information for different dwelling forms and types. More empirical and data driven studies are needed to find the interim thermal comfort baselines for local environmental conditions in residential buildings. In India, the thermal comfort studies particularly in residential buildings are limited, scattered and unorganized in different places and climatic zones as depicted in Figure 11 and Figure 12. Further, this review argues the absence of interdisciplinary research on thermal comfort which is in fact the multidisciplinary activity that brings researchers, engineers, architects, social scientists and policy makers together to dispense quality research on thermal comfort in dwellings. Furthermore, the sharing of thermal comfort data to form online repository could be helpful in developing the local thermal comfort models and standards. The occupant's health has also been observed to be greatly influenced by indoor thermal environment, as stated by global studies available in the literature. Such investigations are also required for both residential and commercial buildings in Indian context. 


\section{Conclusion}

Requirements of thermal comfort particularly in Indian residential buildings have been the principal concerns for healthy survival of human being. However, the present scenario of research in this area requires extensive scientific efforts towards determining the actual comfort requirements. It indicates that the conventional method performed under steady state conditions in laboratory scale is not applicable when focusing on Indian residential buildings having several opportunities of environment adaptations. Therefore, more studies that consider all adaptive possibilities pertinent to the local environmental conditions are required for the upshot of local thermal comfort standards. In the myriads of numerous influencing factors, such investigations become even more crucial and helpful in policy implications for residential thermal comfort and energy in India. This paper intends to present the overview on current research scenario of thermal comfort in Indian dwellings. Residential thermal comfort studies available for different climatic zones of India have been reviewed. The following concluding remarks can be drawn from this review:

- Studies on thermal comfort in Indian residential buildings are scarce, scattered and unorganized. The methods used for analyzing thermal comfort are also inconsistent.

- Due to socio-cultural set-up and adaptation gap, the wide range of comfort temperature is reported in the studies available in India.

- ASHRAE Class II protocol provides more extensive information about individual and mixed environment and therefore, it is followed by most thermal comfort field studies specific to Indian residential buildings.

- Online repository of thermal comfort data obtained could be helpful in developing adaptive thermal comfort models, local standards and policies. Therefore, the sharing of comfort data is required at upfront.

- More empirical and data driven studies are required to be performed locally to establish thermal comfort standards specific to Indian context.

- Interdisciplinary approach is required for quality research on thermal comfort in residential buildings.

\section{Acknowledgement}

This work is supported by the Joint Indo-UK research project (DST/TMD/UKBEE/2017/07) called 'Residential building energy demand reduction in India (RESIDE)' 
funded by Department of Science and Technology (DST), Govt. of India and Engineering and Physical Sciences Research Council (EPSRC), United Kingdom.

\section{References}

Ainsworth, B. E., W. L. Haskell, M. C. Whitt, M. L. Irwin, A. M. Swartz, S. J. Strath, W. L. O’brien, D. R. Bassett, K. H. Schmitz, P. O. Emplaincourt, and D. R. Jacobs. 2000. Compendium of physical activities: an update of activity codes and MET intensities. Medicine \& Science in Sports \& Exercise 32(9):S498-516.

Alfano, F. R., B. I. Palella, G. Riccio, and J. Toftum. 2018. Fifty years of Fanger's equation: Is there anything to discover yet?. International Journal of Industrial Ergonomics 66:157-160.

ASHRAE. 2004. ANSI/ASHRAE Standard 55, Thermal Environmental Conditions for Human Occupancy, Atlanta, USA.

ASHRAE. 2010. ANSI/ASHRAE Standard 55, Thermal Environmental Conditions for Human Occupancy, Atlanta, USA

ASHRAE. 2017. ANSI/ASHRAE Standard 55, Thermal Environmental Conditions for Human Occupancy, Atlanta, USA

Aynsley, R. 2005. Saving energy with indoor air movement. International Journal of Ventilation 4(2):167175.

Aynsley, R. 2008. Quantifying the cooling sensation of air movement. International Journal of Ventilation $7(1): 67-76$.

BEE. 2007. Energy Conservation Building Code. Bureau of Energy Efficiency.

Bin, S., and M. Evans. 2008. Building Energy Codes in APP Countries. 5th Meeting, June 23, 2008, Seoul, Korea: APP Building and Appliances Task Force.

BIS. 2005. National Building Code of India. Bureau of Indian Standards.

BIS. 2016. National building code of India. Bureau of Indian Standards.

Cândido, C., R. J. De Dear, R. Lamberts, and L. Bittencourt. 2010. Air movement acceptability limits and thermal comfort in Brazil's hot humid climate zone. Building and Environment 45(1):222-229.

CEN. 2007. EN 15251, Indoor environmental input parameters for design and assessment of energy performance of buildings addressing indoor air quality, thermal environment, lighting and acoustics. European Committee for Standardization, Brussels, Belgium.

CEN. 2019. EN 16798, Energy performance of buildings - Part 1: Indoor environmental input parameters for design and assessment of energy performance of buildings addressing indoor air quality, thermal environment, lighting and acoustics.

de Dear, R. J., T. Akimoto, E. A. Arens, G. Brager, C. Candido, K. W. Cheong, B. Li, N. Nishihara, S. C. Sekhar, S. Tanabe, and J. Toftum. 2013. Progress in thermal comfort research over the last twenty years. Indoor Air 23(6):442-461.

Dili, A. S., M. A. Naseer, and T. Z. Varghese. 2010. Thermal comfort study of Kerala traditional residential buildings based on questionnaire survey among occupants of traditional and modern buildings. Energy and Buildings 42(11):2139-2150.

Djongyang, N., R. Tchinda, and D. Njomo. 2010. Thermal comfort: A review paper. Renewable And Sustainable Energy Reviews 14(9):2626-2640. 
Fabbri, K. 2015. Indoor Thermal Comfort Perception, Chapter 2, A brief history of thermal comfort: from effective temperature to adaptive thermal comfort. Springer.

Fanger, P. O. 1970. Thermal comfort: Analysis and applications in environmental engineering, 1 st Ed. Michigan: Danish Technical Press.

Gagge, A. P., A. C. Burton, H. C. Bazett. 1941. A practical system of units for the description of the heat exchange of man with his environment. Science 94(2445):428-430.

Garg, N. K. 1991. Passive options for thermal comfort in building envelopes-an assessment. Solar Energy 47(6):437-441.

Humphreys, M. A. 1976. Field studies of thermal comfort compared and applied. The Building Services Engineer 44:27.

Humphreys, M. A., and J. F. Nicol. 2000. Effects of measurement and formulation error on thermal comfort indices in the ASHRAE database of field studies/Discussion. ASHRAE Transactions 106:493.

Humphreys, M.A. 1992. Thermal Comfort Requirements, Climate and Energy. A.A.M. Sayigh, ed. Oxford: Pergamon Press.

Indraganti, M. 2010a. Behavioural adaptation and the use of environmental controls in summer for thermal comfort in apartments in India. Energy and Buildings 42(7):1019-1025.

Indraganti, M. 2010b. Adaptive use of natural ventilation for thermal comfort in Indian apartments. Building and Environment 45(6):1490-1507.

Indraganti, M. 2010c. Using the adaptive model of thermal comfort for obtaining indoor neutral temperature: findings from a field study in Hyderabad, India. Building and Environment 45(3):519536.

Indraganti, M. 2011. Thermal comfort in apartments in India: Adaptive use of environmental controls and hindrances. Renewable Energy 36(4):1182-1189.

Indraganti, M., and K. D. Rao. 2010. Effect of age, gender, economic group and tenure on thermal comfort: a field study in residential buildings in hot and dry climate with seasonal variations. Energy and Buildings 42(3):273-281.

ISO. 2005. ISO7730, Ergonomics of the thermal environment-Analytical determination and interpretation of thermal comfort using calculation of the PMV and PPD indices and local thermal comfort criteria.

Jaboyedoff, P., S. Maithel, A. Lall, Chetia, P. Bhanware, and Reddy. 2017. Energy efficient building envelope \& ventilation strategies for multi-storey residential buildings in India. Inspire Conference.

Kabanshi, A., B. Yang, P. Sörqvist, and M. Sandberg. 2019. Occupants' perception of air movements and air quality in a simulated classroom with an intermittent air supply system. Indoor and Built Environment 28(1):63-76.

Kapoor, N. R., and J. P. Tegar. 2018. Human comfort indicators pertaining to indoor environmental quality parameters of residential buildings in Bhopal. International Research Journal of Engineering and Technology 1744-1750.

Kim, J., A. Tzempelikos, and J.E. Braun. 2019. Energy savings potential of passive chilled beams vs air systems in various US climatic zones with different system configurations. Energy and Buildings 186:244-60. 
Kumar, B., and R. Dibakar. 2017. Comparative assessment of thermal comfort with insulation and phase change materials utilizations in building roofs and walls. Advanced Materials Proceedings 2(6):393397.

Kumar, S., J. Mathur, S. Mathur, M. K. Singh, and V. Loftness. 2016b. An adaptive approach to define thermal comfort zones on psychrometric chart for naturally ventilated buildings in composite climate of India. Building and Environment 109:135-153.

Kumar, S., M. K. Singh, V. Loftness, J. Mathur, and S. Mathur. 2016a. Thermal comfort assessment and characteristics of occupant's behaviour in NV buildings in composite climate of India. Energy for Sustainable Development 33:108-121.

Kumar, S., P. Tewari, S. Mathur, and J. Mathur. 2017. Development of mathematical correlations for indoor temperature from field observations of the performance of high thermal mass buildings in India. Building and Environment 122:324-342.

Manoj, P. K. 2004. Dynamics of Housing Finance in India. Bank Quest 75(3):19-25.

Manu, S., Y. Shukla, R. Rawal, L. Thomas, and R. de Dear. 2016. Field studies of thermal comfort across multiple climate zones for the subcontinent: India Model for Adaptive Comfort (IMAC). Building and Environment 98:55-70.

Mishra, A. K., and M. Ramgopal. 2013. Field studies on human thermal comfort-an overview. Building and Environment 64:94-106.

National Disaster Management Authority. 2013. Compilation of Catalogue of Building Typologies in India. Govt. of India.

Netam, N., S. Sanyal, and S. Bhowmick. 2017. Thermal performance analysis to assess inhabitant comfort inside LIG houses in chhattisgarh. International Journal of Theoretical and Applied Mechanics 12(3):613-622.

Nicol, J. F., and M. Wilson. 2011. A critique of European Standard EN 15251: strengths, weaknesses and lessons for future standards. Building Research \& Information 39(2):183-193.

Nicol, J. F., and M.A. Humphreys. 2002. Adaptive thermal comfort and sustainable thermal standards for buildings. Energy and Buildings 34(6):563-572.

Olesen, B. W., and G. S. Brager. 2004. A better way to predict comfort. ASHRAE Journal 46(8):20-26.

Parsons, K. C. 2001. Introduction to thermal comfort standards. Paper presented at Windsor Conference: Moving Thermal Comfort Standards into the 21st Century, Cumberland Lodge, UK.

Ponni, M., and R. Baskar. 2017. Summer thermal performance of a multi-storeyed residential building. International Journal of Engineering Science Invention 6(2):1-7

Praseeda, K. I., M. Mani, and B. V. Reddy. 2014. Assessing impact of material transition and thermal comfort models on embodied and operational energy in vernacular dwellings (India). Energy Procedia $54: 342-351$

Prek, M. 2005. Thermodynamic analysis of human heat and mass transfer and their impact on thermal comfort. International Journal of Heat and Mass Transfer 48(3-4):731-739.

Rajasekar, E., and A. Ramachandraiah. 2010. Adaptive comfort and thermal expectations-a subjective evaluation in hot humid climate. Proceedings of the adapting to change: new thinking on comfort. Windsor, London, UK, April 9-11. 
Rao, P., and Y. Patil. 2016. Reconsidering the Impact of Climate Change on Global Water Supply, Use, and Management. IGI Global.

Roaf, S., F. Nicol, M. Humphreys, P. Tuohy, and A. Boerstra. 2012. Twentieth century standards for thermal comfort: promoting high energy buildings. Architectural Science Review 53:65-77.

Schaudienst, F., and F. U. Vogdt. 2017. Fanger's model of thermal comfort: a model suitable just for men?. Energy Procedia 132:129-134.

Sharma, A., and R. Tiwari. 2007. Evaluation of data for developing an adaptive model of thermal comfort and preference. The Environmentalist 27(1):73-81.

Sharma, M. R., and S. Ali. 1986. Tropical summer index-a study of thermal comfort of Indian subjects. Building and Environment 21(1):11-24.

Shastry, V., M. Mani, and R. Tenorio. 2014. Impacts of modern transitions on thermal comfort in vernacular dwellings in warm-humid climate of Sugganahalli (India). Indoor and Built Environment 23(4):543-564.

Singh, M. K., S. Mahapatra, and J. Teller. 2015. Development of thermal comfort models for various climatic zones of North-East India. Sustainable Cities and Society 14:133-145.

Singh, M. K., S. Mahapatra, and S. K. Atreya. 2009. Bioclimatism and vernacular architecture of north-east India. Building and Environment 44(5):878-888.

Singh, M. K., S. Mahapatra, and S. K. Atreya. 2010b. Thermal performance study and evaluation of comfort temperatures in vernacular buildings of North-East India. Building and Environment 45(2):320-329.

Singh, M. K., S. Mahapatra, and S. K. Atreya. 2011. Adaptive thermal comfort model for different climatic zones of North-East India. Applied Energy 88(7):2420-2428.

Singh, M. K., S. Mahapatra, S. K. Atreya, and B. Givoni. 2010a. Thermal monitoring and indoor temperature modeling in vernacular buildings of North-East India. Energy and Buildings 42(10):1610-1618.

Singh, S., and P. S. Chani. 2018. Thermal comfort analysis of Indian subjects in multi-storeyed apartments: An adaptive approach in composite climate. Indoor and Built Environment 27(9):1216-1246.

Sthapak, S., and A. Bandyopadhyay. 2017. Thermal comfort in vernacular courtyard houses: case studychhattisgarh. International Journal of Engineering Sciences \& Research Technology. 6(12):487-490.

Subramanian, C., N. Ramachandran, and S. S. Kumar. 2017. Design and analysis of solar passive architecture for thermal comfort of residential buildings in warm-humid climate of thanjavur region. Indian Journal of Science and Technology 10(9):1-8.

Thapa, S. 2019. Thermal comfort in high altitude Himalayan residential houses in Darjeeling, India-An adaptive approach. Indoor and Built Environment 0(0):1-17.

Thapa, S., A. K. Bansal, and G. K. Panda. 2017. Adaptive thermal comfort in the residential buildings of north east India-An effect of difference in elevation. Building Simulation 11(2): 245-267.

Udaykumar, A., E. Rajasekar, and R. Venkateswaran. 2015. Thermal comfort characteristics in naturally ventilated, residential apartments in a hot-dry climate of India. Indoor and Built Environment 24(1):101-115.

Van Hoof, J., and J. L. Hensen. 2007. Quantifying the relevance of adaptive thermal comfort models in moderate thermal climate zones. Building and Environment 42(1):156-170. 
Wang, C., Y. Zhu, and X. Guo. 2019. Thermally responsive coating on building heating and cooling energy efficiency and indoor comfort improvement. Applied Energy 253:113506.

Yau, Y. H., and B. T. Chew. 2014. A review on predicted mean vote and adaptive thermal comfort models. Building Services Engineering Research and Technology 35(1):23-35.

Zamani, Z., S. Heidari, M. Azmoodeh, and M. Taleghani. 2019. Energy performance and summer thermal comfort of traditional courtyard buildings in a desert climate. Environmental Progress \& Sustainable Energy DOI: 10.1002/ep.13256

Zhai, Y., F. Miao, L. Yang, S. Zhao, H. Zhang, and E. Arens. 2019. Using personally controlled air movement to improve comfort after simulated summer commute. Building and Environment 165:106329.

Zhao, B., M. Hu, X. Ao, N. Chen, and G. Pei. 2019. Radiative cooling: A review of fundamentals, materials, applications, and prospects. Applied Energy 236:489-513.

Zhao, Y., H. Sun, and D. Tu. 2018. Effect of mechanical ventilation and natural ventilation on indoor climates in Urumqi residential buildings. Building and Environment 144:108-118.

\section{Appendix}

Table 2. Research papers on thermal comfort studies specific to Indian residential buildings.

\begin{tabular}{|c|c|c|c|c|}
\hline $\begin{array}{l}\text { S. } \\
\text { No. }\end{array}$ & Article title & Authors & Journal Name & $\begin{array}{l}\text { No. of } \\
\text { citations* }\end{array}$ \\
\hline \multicolumn{5}{|c|}{$\begin{array}{ll} & \text { Journal Papers } \\
\end{array}$} \\
\hline 1 & $\begin{array}{l}\text { Passive options for thermal comfort in } \\
\text { building envelopes--an assessment }\end{array}$ & Garg (1991) & Solar Energy & 6 \\
\hline 2 & $\begin{array}{l}\text { Evaluation of data for developing an } \\
\text { adaptive model of thermal comfort and } \\
\text { preference }\end{array}$ & $\begin{array}{l}\text { Sharma and } \\
\text { Tiwari } \\
(2007)\end{array}$ & Environmentalist & 10 \\
\hline 3 & $\begin{array}{l}\text { Bioclimatism and vernacular architecture } \\
\text { of north-east India }\end{array}$ & $\begin{array}{l}\text { Singh et al. } \\
(2009)\end{array}$ & $\begin{array}{l}\text { Building and } \\
\text { Environment }\end{array}$ & 122 \\
\hline 4 & $\begin{array}{l}\text { Thermal comfort study of Kerala } \\
\text { traditional residential buildings based on } \\
\text { questionnaire survey among occupants of } \\
\text { traditional and modern buildings }\end{array}$ & $\begin{array}{l}\text { Dili et al. } \\
(2010)\end{array}$ & $\begin{array}{ll}\text { Energy } & \text { and } \\
\text { Buildings } & \end{array}$ & 66 \\
\hline 5 & $\begin{array}{l}\text { Thermal monitoring and indoor } \\
\text { temperature modeling in vernacular } \\
\text { buildings of north-east India }\end{array}$ & $\begin{array}{l}\text { Singh et al. } \\
(2010 a)\end{array}$ & $\begin{array}{l}\text { Energy } \\
\text { Buildings }\end{array}$ & 33 \\
\hline 6 & $\begin{array}{l}\text { Thermal performance study and } \\
\text { evaluation of comfort temperatures in } \\
\text { vernacular buildings of north-east India }\end{array}$ & $\begin{array}{l}\text { Singh et al. } \\
(2010 \mathrm{~b})\end{array}$ & $\begin{array}{l}\text { Building and } \\
\text { Environment }\end{array}$ & 138 \\
\hline 7 & $\begin{array}{l}\text { Effect of age, gender, economic group and } \\
\text { tenure on thermal comfort: a field study } \\
\text { in residential buildings in hot and dry } \\
\text { climate with seasonal variations }\end{array}$ & $\begin{array}{l}\text { Indraganti } \\
\text { and Rao } \\
(2010)\end{array}$ & $\begin{array}{l}\text { Energy } \\
\text { Buildings }\end{array}$ & 180 \\
\hline 8 & $\begin{array}{l}\text { Behavioural adaptation and the use of } \\
\text { environmental controls in summer for } \\
\text { thermal comfort in apartments in India }\end{array}$ & $\begin{array}{l}\text { Indraganti } \\
\text { (2010a) }\end{array}$ & $\begin{array}{l}\text { Energy } \\
\text { Buildings }\end{array}$ & 63 \\
\hline 9 & $\begin{array}{l}\text { Adaptive use of natural ventilation for } \\
\text { thermal comfort in Indian apartments }\end{array}$ & $\begin{array}{l}\text { Indraganti } \\
(2010 \mathrm{~b})\end{array}$ & $\begin{array}{ll}\text { Building and } \\
\text { Environment }\end{array}$ & 87 \\
\hline 10 & $\begin{array}{l}\text { Using the adaptive model of thermal } \\
\text { comfort for obtaining indoor neutral } \\
\text { temperature: findings from a field study } \\
\text { in Hyderabad, India }\end{array}$ & $\begin{array}{l}\text { Indraganti } \\
\text { (2010c) }\end{array}$ & $\begin{array}{l}\text { Building and } \\
\text { Environment }\end{array}$ & 91 \\
\hline 11 & Thermal comfort in apartments in india: & Indraganti & Renewable Energy & 40 \\
\hline
\end{tabular}




\begin{tabular}{|c|c|c|c|c|}
\hline & $\begin{array}{l}\text { adaptive use of environmental controls } \\
\text { and hindrances }\end{array}$ & (2011) & & \\
\hline 12 & $\begin{array}{l}\text { Adaptive thermal comfort model for } \\
\text { different climatic zones of north-east } \\
\text { India }\end{array}$ & $\begin{array}{l}\text { Singh et al. } \\
(2011)\end{array}$ & Applied Energy & 126 \\
\hline 13 & $\begin{array}{l}\text { Field studies on human thermal comfort } \\
\text { - an overview }\end{array}$ & $\begin{array}{l}\text { Mishra and } \\
\text { Ramgopal } \\
(2013)\end{array}$ & $\begin{array}{ll}\text { Building and } \\
\text { Environment }\end{array}$ & 190 \\
\hline 14 & $\begin{array}{l}\text { Impacts of modern transitions on thermal } \\
\text { comfort in vernacular dwellings in warm- } \\
\text { humid climate of Sugganahalli (India) }\end{array}$ & $\begin{array}{l}\text { Shastry et al. } \\
(2014)\end{array}$ & $\begin{array}{l}\text { Indoor and Built } \\
\text { Environment }\end{array}$ & 19 \\
\hline 15 & $\begin{array}{l}\text { Development of thermal comfort models } \\
\text { for various climatic zones of north-east } \\
\text { India }\end{array}$ & $\begin{array}{l}\text { Singh et al. } \\
(2015)\end{array}$ & $\begin{array}{l}\text { Sustainable Cities } \\
\text { and Society }\end{array}$ & 27 \\
\hline 16 & $\begin{array}{l}\text { Thermal comfort characteristics in } \\
\text { naturally } \quad \text { ventilated, residential } \\
\text { apartments in a hot-dry climate of India }\end{array}$ & $\begin{array}{l}\text { Udaykumar } \\
\text { et al. (2015) }\end{array}$ & $\begin{array}{l}\text { Indoor and Built } \\
\text { Environment }\end{array}$ & 12 \\
\hline 17 & $\begin{array}{l}\text { Thermal comfort assessment and } \\
\text { characteristics of occupant's behaviour in } \\
\text { NV buildings in composite climate of India }\end{array}$ & $\begin{array}{l}\text { Kumar et al. } \\
(2016 a)\end{array}$ & $\begin{array}{ll}\text { Energy for } \\
\text { Sustainable }\end{array}$ & 29 \\
\hline 18 & $\begin{array}{l}\text { An adaptive approach to define thermal } \\
\text { comfort zones on psychrometric chart for } \\
\text { naturally ventilated buildings in } \\
\text { composite climate of India }\end{array}$ & $\begin{array}{l}\text { Kumar et al. } \\
(2016 b)\end{array}$ & $\begin{array}{l}\text { Building and } \\
\text { Environment }\end{array}$ & 43 \\
\hline 19 & $\begin{array}{l}\text { Adaptive thermal comfort in the } \\
\text { residential buildings of north east India- } \\
\text { an effect of difference in elevation }\end{array}$ & $\begin{array}{l}\text { Thapa et al. } \\
\text { (2017) }\end{array}$ & $\begin{array}{l}\text { Building } \\
\text { Simulation }\end{array}$ & 4 \\
\hline 20 & $\begin{array}{l}\text { Thermal comfort analysis of Indian } \\
\text { subjects in multi-storeyed apartments: an } \\
\text { adaptive approach in composite climate }\end{array}$ & $\begin{array}{l}\text { Singh and } \\
\text { Chani (2017) }\end{array}$ & $\begin{array}{l}\text { Indoor and Built } \\
\text { Environment }\end{array}$ & 1 \\
\hline 21 & $\begin{array}{l}\text { Thermal performance analysis to assess } \\
\text { inhabitant comfort inside LIG houses in } \\
\text { Chhattisgarh }\end{array}$ & $\begin{array}{l}\text { Netam et al. } \\
(2017)\end{array}$ & $\begin{array}{l}\text { International } \\
\text { Journal of } \\
\text { Theoretical and } \\
\text { Applied Mechanics }\end{array}$ & - \\
\hline 22 & $\begin{array}{l}\text { Comparative assessment of thermal } \\
\text { comfort with insulation and phase change } \\
\text { materials utilizations in building roofs } \\
\text { and walls }\end{array}$ & $\begin{array}{l}\text { Kumar and } \\
\text { Dibakar } \\
(2017)\end{array}$ & $\begin{array}{l}\text { Advanced } \\
\text { Materials } \\
\text { Proceedings }\end{array}$ & 4 \\
\hline 23 & $\begin{array}{l}\text { Design and analysis of solar passive } \\
\text { architecture } \\
\text { For thermal comfort of residential } \\
\text { buildings in } \\
\text { Warm-humid climate of Thanjavur region }\end{array}$ & $\begin{array}{l}\text { Subramanian } \\
\text { et al. (2017) }\end{array}$ & $\begin{array}{l}\text { Indian Journal of } \\
\text { Science and } \\
\text { Technology }\end{array}$ & 1 \\
\hline 24 & $\begin{array}{l}\text { Summer thermal performance of a } \\
\text { multistoried residential building }\end{array}$ & $\begin{array}{l}\text { Ponni and } \\
\text { Baskar } \\
(2017)\end{array}$ & $\begin{array}{l}\text { International } \\
\text { Journal of } \\
\text { Engineering } \\
\text { Science Invention } \\
\end{array}$ & - \\
\hline 25 & $\begin{array}{l}\text { Thermal comfort in vernacular courtyard } \\
\text { houses: case study -Chhattisgarh }\end{array}$ & $\begin{array}{l}\text { Sthapak and } \\
\text { Bandyopadhy } \\
\text { ay (2017) }\end{array}$ & $\begin{array}{ll}\text { International } & \\
\text { Journal } & \text { of } \\
\text { Engineering } & \\
\text { Sciences } & \& \\
\text { Research } & \\
\text { Technology } & \\
\end{array}$ & - \\
\hline 26 & $\begin{array}{l}\text { Human comfort indicators pertaining to } \\
\text { indoor environmental quality parameters } \\
\text { of residential buildings in Bhopal }\end{array}$ & $\begin{array}{l}\text { Kapoor and } \\
\text { Tegar (2018) }\end{array}$ & $\begin{array}{l}\text { International } \\
\text { Research Journal } \\
\text { of Engineering and } \\
\text { Technology }\end{array}$ & - \\
\hline 27 & Thermal comfort in high altitude & Thapa (2019) & Indoor and Built & - \\
\hline
\end{tabular}




\begin{tabular}{|l|l|l|l|c|}
\hline & $\begin{array}{l}\text { Himalayan residential houses in } \\
\text { Darjeeling, India - An } \\
\text { adaptive approach }\end{array}$ & Environment & 30 \\
\hline 28 & $\begin{array}{l}\text { Adaptive comfort and thermal } \\
\text { expectations - a subjective evaluation in } \\
\text { hot humid climate }\end{array}$ & $\begin{array}{l}\text { Rajasekar } \\
\text { and } \\
\text { Ramachandra } \\
\text { iah (2010) }\end{array}$ & Windsor & 17 \\
\hline 29 & $\begin{array}{l}\text { Assessing Impact of Material Transition } \\
\text { and Thermal Comfort Models on } \\
\text { Embodied and Operational Energy in } \\
\text { Vernacular Dwellings (India) }\end{array}$ & $\begin{array}{l}\text { Praseeda et } \\
\text { al. (2014) }\end{array}$ & ICAER & - \\
\hline 30 & $\begin{array}{l}\text { Energy efficient building envelope \& Jaboyedoff et } \\
\text { ventilation strategies for Multi-storey } \\
\text { residential buildings in India }\end{array}$ & $\begin{array}{l}\text { Inspire } \\
\text { al. (2017) }\end{array}$ & & \\
\hline
\end{tabular}

* As on 07.09.2019 
Table 3. Summary of thermal comfort studies in Indian residential buildings.

\begin{tabular}{|c|c|c|c|c|c|c|c|c|c|c|c|c|}
\hline Researcher & $\begin{array}{l}\text { Study } \\
\text { place }\end{array}$ & $\begin{array}{c}\text { Study } \\
\text { type }\end{array}$ & $\begin{array}{c}\text { Building } \\
\text { type }\end{array}$ & $\begin{array}{l}\begin{array}{l}\text { Climatic } \\
\text { region }\end{array} \\
\end{array}$ & \begin{tabular}{|c|}
$\begin{array}{c}\text { Season } \\
\text { considered }\end{array}$ \\
\end{tabular} & \begin{tabular}{|c|}
$\begin{array}{c}\text { No. of } \\
\text { dwellings }\end{array}$ \\
\end{tabular} & Subjects & Method used & Parameters & $\begin{array}{c}\text { Instruments } \\
\text { used }\end{array}$ & $\begin{array}{c}\text { Model } \\
\text { Equation }\end{array}$ & \begin{tabular}{|c|c|} 
Comfort \\
temp $\left({ }^{\circ} \mathrm{C}\right)$
\end{tabular} \\
\hline Garg (1991) & New Delhi & $\begin{array}{c}\text { Simulation } \\
\text { work }\end{array}$ & $\begin{array}{l}\text { Isolated } \\
\text { room }\end{array}$ & Composite & Summer & 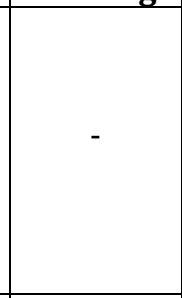 & - & $\begin{array}{l}\text { Energy } \\
\text { simulation and } \\
\text { heat transfer } \\
\text { modeling }\end{array}$ & $\begin{array}{c}\text { Building } \\
\text { components, } \\
\text { ambient } \\
\text { temperature, } \\
\text { direct and } \\
\text { diffused } \\
\text { radiation } \\
\end{array}$ & $\begin{array}{l}\text { Simulation } \\
\text { Program }\end{array}$ & 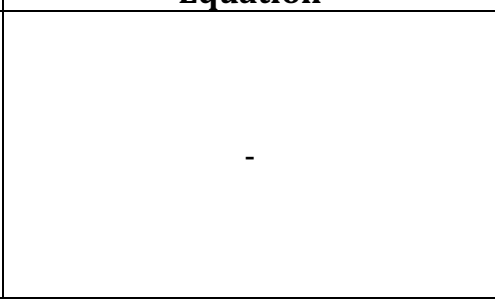 & $27^{\circ} \mathrm{C}$ \\
\hline $\begin{array}{c}\text { Sharma and } \\
\text { Tiwari } \\
(2007)\end{array}$ & Bhopal & Field study & - & Composite & $\begin{array}{c}\text { Summer and } \\
\text { winter }\end{array}$ & 10 & 200 & $\begin{array}{c}\text { Subjective and } \\
\text { objective } \\
\text { analysis }\end{array}$ & $\begin{array}{l}\text { RAT, MRT, RH, } \\
\text { air velocity, } \\
\text { clothing and } \\
\text { activity }\end{array}$ & $\begin{array}{c}\text { Digital } \\
\text { thermometers } \\
\text { and digital } \\
\text { hygrometer } \\
\text { and vane } \\
\text { anemometer }\end{array}$ & - & $20-30^{\circ} \mathrm{C}$ \\
\hline $\begin{array}{l}\text { Singh et al. } \\
\text { (2009) }\end{array}$ & $\begin{array}{l}\text { North-East } \\
\text { India }\end{array}$ & $\begin{array}{l}\text { Field } \\
\text { survey }\end{array}$ & $\begin{array}{l}\text { Traditional } \\
\text { houses }\end{array}$ & $\begin{array}{l}\text { Warm- } \\
\text { humid and } \\
\text { Cold }\end{array}$ & $\begin{array}{c}\text { Summer and } \\
\text { winter }\end{array}$ & 42 & - & $\begin{array}{l}\text { Theoretical } \\
\text { evaluation }\end{array}$ & $\begin{array}{c}\text { Illumination } \\
\text { levels, external } \\
\text { wall thickness, } \\
\text { inter-room } \\
\text { partition } \\
\text { thickness, false } \\
\text { ceiling height } \\
\text { and dimensions } \\
\text { of doors and } \\
\text { windows }\end{array}$ & - & - & - \\
\hline $\begin{array}{l}\text { Dili et al. } \\
(2010)\end{array}$ & Kerala & Field study & $\begin{array}{l}\text { Single and } \\
\text { multi storey }\end{array}$ & $\begin{array}{l}\text { Warm- } \\
\text { humid }\end{array}$ & $\begin{array}{c}\text { Winter, } \\
\text { summer and } \\
\text { monsoon }\end{array}$ & 50 & 200 & $\begin{array}{c}\text { PMV-PPD } \\
\text { analysis and } \\
\text { Bioclimatic } \\
\text { chart } \\
\end{array}$ & $\begin{array}{l}\text { RAT, RH and air } \\
\text { flow }\end{array}$ & $\begin{array}{c}\text { Questionnaire } \\
\text { survey }\end{array}$ & (5) & $23.5-32^{\circ} \mathrm{C}$ \\
\hline $\begin{array}{l}\text { Singh et al. } \\
\text { (2010a) }\end{array}$ & $\begin{array}{c}\text { Tezpur, } \\
\text { Cherrapunje } \\
\mathrm{e}\end{array}$ & Field study & $\begin{array}{c}\text { Single storey } \\
\text { houses }\end{array}$ & $\begin{array}{l}\text { Warm- } \\
\text { humid and } \\
\text { Cold }\end{array}$ & $\begin{array}{c}\text { Summer, } \\
\text { Pre-summer, } \\
\text { Winter and } \\
\text { Pre-winter }\end{array}$ & 2 & 7 & $\begin{array}{l}\text { Multiple } \\
\text { regression }\end{array}$ & $\begin{array}{c}\text { RAT, RH, } \\
\text { ambient tem., } \\
\text { illumination } \\
\text { level and } \\
\text { building design } \\
\text { parameters } \\
\end{array}$ & $\begin{array}{c}\text { Questionnaire } \\
\text { survey, HOBO } \\
\text { data loggers }\end{array}$ & $\begin{array}{l}I_{\text {avg }}=1.1+0.0 / 1 J \times I_{\max }+0.8910 \times I_{\text {avg }} \\
-0.0316 \times S_{\text {wg }}+2 \times I l l(\text { Cherrapunjee })\end{array}$ & - \\
\hline
\end{tabular}




\begin{tabular}{|c|c|c|c|c|c|c|c|c|c|c|c|c|}
\hline $\begin{array}{l}\text { Singh et al. } \\
\text { (2010b) }\end{array}$ & $\begin{array}{c}\text { Tezpur, } \\
\text { Imphal and } \\
\text { Cherrapunje } \\
\text { e }\end{array}$ & Field study & $\begin{array}{l}\text { Vernacular } \\
\text { buildings }\end{array}$ & $\begin{array}{l}\text { Warm- } \\
\text { humid and } \\
\text { Cold }\end{array}$ & $\begin{array}{c}\text { Summer, } \\
\text { Pre-summer, } \\
\text { and Winter }\end{array}$ & 150 & 300 & $\begin{array}{l}\text { Linear } \\
\text { regression }\end{array}$ & $\begin{array}{c}\text { RAT, RH, } \\
\text { illuminance and } \\
\text { Building design } \\
\text { parameters }\end{array}$ & $\begin{array}{c}\text { Questionnaire } \\
\text { survey, HOBO } \\
\text { data loggers }\end{array}$ & $T_{\text {com }}=0.53 \times T_{m}+11.9$ & $19-29 .{ }^{\circ} \mathrm{C}$ \\
\hline $\begin{array}{c}\text { Indraganti } \\
\text { and Rao } \\
(2010)\end{array}$ & \multirow{4}{*}{ Hyderabad } & \multirow{4}{*}{ Field study } & \multirow{4}{*}{ Apartments } & \multirow{4}{*}{ Composite } & \multirow{4}{*}{$\begin{array}{c}\text { Summer and } \\
\text { monsoon }\end{array}$} & 5 & 113 & \multirow[t]{2}{*}{$\begin{array}{l}\text { Linear } \\
\text { regression }\end{array}$} & \multirow{4}{*}{$\begin{array}{l}\text { RAT, GT, RH, } \\
\text { and air velocity, } \\
\text { gender, income, } \\
\text { lifestyle, } \\
\text { clothing, } \\
\text { activity level, } \\
\text { thermal } \\
\text { responses }\end{array}$} & \multirow{4}{*}{$\begin{array}{l}\text { Digital } \\
\text { thermometer, } \\
\text { vane } \\
\text { Anemometer, } \\
\text { lux meter and } \\
\text { Questionnaire } \\
\text { survey }\end{array}$} & te & $\begin{array}{c}27.3-33.1 \\
{ }^{\circ} \mathrm{C}\end{array}$ \\
\hline $\begin{array}{c}\text { Indraganti } \\
(2010 \mathrm{a})\end{array}$ & & & & & & 5 & 100 & & & & $T S V=0.258 \times T_{g}-7.077$ & \multirow{3}{*}{$\begin{array}{c}26- \\
32.5^{\circ} \mathrm{C}\end{array}$} \\
\hline $\begin{array}{c}\text { Indraganti } \\
(2010 \mathrm{~b})\end{array}$ & & & & & & 5 & 113 & \multirow{2}{*}{$\begin{array}{l}\text { Polygonal } \\
\text { regression } \\
\text { analysis }\end{array}$} & & & $T S V=0.31 \times T_{g}-9.06$ & \\
\hline $\begin{array}{l}\text { Indraganti } \\
(2010 \mathrm{c})\end{array}$ & & & & & & 5 & 113 & & & & $T_{n}=0.506 \times T_{g}+11.39$ & \\
\hline $\begin{array}{c}\text { Rajasekar } \\
\text { and } \\
\text { Ramachandr } \\
\text { aiah (2010) }\end{array}$ & Chennai & $\begin{array}{c}\text { Field } \\
\text { survey and } \\
\text { experimen } \\
\text { tal work }\end{array}$ & Apartments & $\begin{array}{l}\text { Warm- } \\
\text { humid }\end{array}$ & $\begin{array}{c}\text { Summer and } \\
\text { winter }\end{array}$ & - & 295 & $\begin{array}{c}\text { Subjective and } \\
\text { objective } \\
\text { analysis }\end{array}$ & \begin{tabular}{|} 
RAT, RH, \\
ambient tem., \\
air speed, GT
\end{tabular} & \begin{tabular}{|c|} 
IEQ \\
monitoring \\
system, \\
thermal \\
comfort meter, \\
thermocouples \\
connected and \\
data logger \\
\end{tabular} & $\begin{array}{l}T S I \stackrel{T S V}{=}=0.308 \times 34 \times T_{0}-9.742 \times T_{g} \\
-2.06 \times \sqrt{V_{a}}+0.841\end{array}$ & $27-29^{\circ} \mathrm{C}$ \\
\hline $\begin{array}{l}\text { Indraganti } \\
(2011)\end{array}$ & Hyderabad & Field study & Apartments & Composite & $\begin{array}{c}\text { Summer and } \\
\text { monsoon }\end{array}$ & 5 & 113 & $\begin{array}{l}\text { Linear } \\
\text { regression }\end{array}$ & \begin{tabular}{|c|} 
RAT, GT, RH, \\
and air velocity, \\
gender, income, \\
lifestyle, \\
clothing, \\
activity level, \\
thermal comfort \\
responses \\
\end{tabular} & $\begin{array}{l}\text { Digital } \\
\text { thermometer, } \\
\text { vane } \\
\text { Anemometer, } \\
\text { lux meter and } \\
\text { Questionnaire } \\
\text { survey }\end{array}$ & $T S V=0.31 \times T_{g}-9.06$ & $\begin{array}{c}26- \\
32.5^{\circ} \mathrm{C}\end{array}$ \\
\hline $\begin{array}{l}\text { Singh et al. } \\
\text { (2011) }\end{array}$ & $\begin{array}{l}\text { North-East } \\
\text { India }\end{array}$ & Field study & $\begin{array}{l}\text { Vernacular } \\
\text { houses }\end{array}$ & $\begin{array}{l}\text { Warm- } \\
\text { humid and } \\
\text { Cold }\end{array}$ & \begin{tabular}{|c|} 
Summer, \\
Pre-summer, \\
Winter and \\
Pre-winter
\end{tabular} & 150 & 300 & $\begin{array}{l}\text { Polynomial } \\
\text { regression, } \\
\text { Linear } \\
\text { regression, } \\
\text { Least square } \\
\text { method }\end{array}$ & \begin{tabular}{|c|} 
RAT, ambient \\
tem., MRT, RH, \\
air velocity, \\
thermal \\
responses, \\
activity and \\
clothing levels. \\
\end{tabular} & $\begin{array}{c}\text { Questionnaire } \\
\text { survey, HOBO } \\
\text { data loggers }\end{array}$ & - & $19-29.1^{\circ} \mathrm{C}$ \\
\hline
\end{tabular}




\begin{tabular}{|c|c|c|c|c|c|c|c|c|c|c|c|c|}
\hline $\begin{array}{c}\text { Shastry et al. } \\
\text { (2014) }\end{array}$ & Sugganahalli & $\mathrm{i} \begin{array}{c}\text { Field study } \\
\text { and } \\
\text { simulation }\end{array}$ & $\begin{array}{l}\text { Courtyard } \\
\text { house }\end{array}$ & $\begin{array}{l}\text { Warm- } \\
\text { humid }\end{array}$ & $\begin{array}{c}\text { Summer and } \\
\text { winter }\end{array}$ & 20 & - & $\begin{array}{c}\text { Building } \\
\text { simulation } \\
\text { model using } \\
\text { DesignBuilder }\end{array}$ & \begin{tabular}{|c|} 
Indoor \\
parameters \\
(RAT, RH, wind \\
velocity) and \\
outdoor \\
parameters \\
(temperature, \\
RH, solar \\
intensity and \\
wind speed) \\
\end{tabular} & \begin{tabular}{|c|} 
Calibrated \\
resistance \\
temperature \\
detector based \\
data-loggers \\
and whirling \\
psychrometer
\end{tabular} & 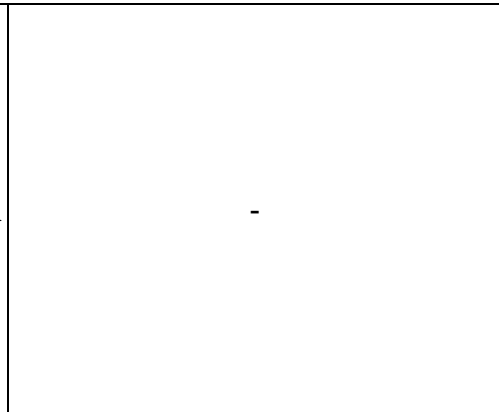 & - \\
\hline $\begin{array}{c}\text { Praseeda et } \\
\text { al. (2014) }\end{array}$ & $\begin{array}{l}\text { Sugganahalli } \\
\text {, Karnataka }\end{array}$ & i $\begin{array}{c}\text { Simulation } \\
\text { work }\end{array}$ & $\begin{array}{c}\text { Vernacular } \\
\text { houses }\end{array}$ & $\begin{array}{l}\text { Warm- } \\
\text { humid }\end{array}$ & $\begin{array}{c}\text { Summer and } \\
\text { winter }\end{array}$ & - & - & $\begin{array}{c}\text { Physical } \\
\text { measurement, } \\
\text { dynamic } \\
\text { simulation }\end{array}$ & $\begin{array}{l}\text { Temperature, } \\
\text { humidity, air } \\
\text { velocity, solar } \\
\text { intensity, } \\
\text { building } \\
\text { construction } \\
\text { details, } \\
\text { occupancy, } \\
\text { activity } \\
\text { patterns }\end{array}$ & $\begin{array}{l}\text { Data loggers, } \\
\text { resistance } \\
\text { temperature } \\
\text { detector and } \\
\text { whirling } \\
\text { Psychrometer, } \\
\text { DesignBuilder } \\
\text { simulation }\end{array}$ & - & $19-34^{\circ} \mathrm{C}$ \\
\hline $\begin{array}{l}\text { Singh et al. } \\
\text { (2015) }\end{array}$ & $\begin{array}{c}\text { Tezpur, } \\
\text { Imphal and } \\
\text { Cherrapunje } \\
\mathrm{e}\end{array}$ & Field study & $\begin{array}{c}\text { Vernacular } \\
\text { houses }\end{array}$ & $\begin{array}{l}\text { Warm- } \\
\text { humid and } \\
\text { Cold }\end{array}$ & $\begin{array}{c}\text { Summer, } \\
\text { Pre-summer, } \\
\text { Winter and } \\
\text { Pre-winter }\end{array}$ & 150 & 300 & $\begin{array}{l}\text { Multiple } \\
\text { regression }\end{array}$ & $\begin{array}{c}\text { Indoor and } \\
\text { outdoor } \\
\text { temperatures, } \\
\text { RH, illuminance } \\
\text { level and } \\
\text { clothing level }\end{array}$ & $\begin{array}{c}\text { Questionnaire } \\
\text { survey, HOBO } \\
\text { data loggers }\end{array}$ & $\begin{array}{l}T_{n}=20.56+0.18 \times T_{O}(\text { Cool }- \text { humid }) \\
T_{n}=17.86+0.22 \times T_{O}(\text { Cold }- \text { cloudy })\end{array}$ & $19-29.1^{\circ} \mathrm{C}$ \\
\hline $\begin{array}{l}\text { Udaykumar } \\
\text { et al. (2015) }\end{array}$ & Ahmedabad & $\begin{array}{c}\text { Field study } \\
\text { and } \\
\text { simulation }\end{array} \mid$ & Apartments & Hot-dry & $\begin{array}{l}\text { Winter and } \\
\text { summer }\end{array}$ & 2 & - & $\begin{array}{l}\text { Regression } \\
\text { analysis and } \\
\text { dynamic } \\
\text { simulation }\end{array}$ & $\begin{array}{c}\text { Indoor and } \\
\text { outdoor } \\
\text { temperatures, } \\
\text { RH, air velocity, } \\
\text { GT, wall surface } \\
\text { temperatures, } \\
\text { PMV }\end{array}$ & \begin{tabular}{|} 
Delta OHM \\
thermal \\
comfort \\
meters and \\
Delta OHM 16 \\
channel data \\
loggers
\end{tabular} & $T_{c o m}=0.31 \times T_{O}+17.8$ & $21-31^{\circ} \mathrm{C}$ \\
\hline
\end{tabular}




\begin{tabular}{|c|c|c|c|c|c|c|c|c|c|c|c|c|}
\hline $\begin{array}{c}\text { Kumar et al. } \\
\text { (2016a) }\end{array}$ & Jaipur & Field study & \multirow[t]{2}{*}{$\begin{array}{l}\text { Single and } \\
\text { multi storey }\end{array}$} & Composite & $\begin{array}{l}\text { Summer, } \\
\text { winter, } \\
\text { moderate }\end{array}$ & 32 & - & $\begin{array}{c}\text { Linear } \\
\text { regression, } \\
\text { Griffiths method }\end{array}$ & $\begin{array}{l}\text { RAT, RH, air } \\
\text { velocity } \\
\text { lighting, } \\
\text { clothing level } \\
\text { and metabolic } \\
\text { activity }\end{array}$ & \begin{tabular}{|c|} 
Testo $480 \mathrm{VAC}$ \\
Testo $435-2$ \\
LUTRON \\
weather \\
station for \\
outdoor \\
parameter
\end{tabular} & $\begin{array}{l}T S V=0.148 \times T_{a}-3.98 \\
T S V=0.149 \times T_{o p}-4.05\end{array}$ & $21-33.1^{\circ} \mathrm{C}$ \\
\hline $\begin{array}{c}\text { Kumar et al. } \\
(2016 b)\end{array}$ & Jaipur & Field study & & Composite & $\begin{array}{l}\text { Summer, } \\
\text { winter, } \\
\text { moderate }\end{array}$ & 32 & - & $\begin{array}{c}\text { ASHRAE } 55 \text { and } \\
\text { ISO } 7730 \\
\text { calculations }\end{array}$ & $\begin{array}{c}\text { RAT, RH, air } \\
\text { velocity } \\
\text { lighting, } \\
\text { clothing level } \\
\text { and metabolic } \\
\text { activity }\end{array}$ & \begin{tabular}{|c|} 
Testo $480 \mathrm{VAC}$, \\
Testo $435-2$ \\
LUTRON \\
weather \\
station for \\
outdoor \\
parameter \\
\end{tabular} & - & $16-35^{\circ} \mathrm{C}$ \\
\hline $\begin{array}{l}\text { Thapa et al. } \\
\text { (2017) }\end{array}$ & Darjeeling & Field study & $\begin{array}{l}\text { Multi } \\
\text { storey }\end{array}$ & Cold & $\begin{array}{l}\text { Summer, } \\
\text { winter, } \\
\text { monsoon }\end{array}$ & 6 & 46 & $\begin{array}{c}\text { Linear } \\
\text { regression, } \\
\text { Griffiths method }\end{array}$ & $\begin{array}{l}\text { RAT, GT and } \\
\text { RH, TSV, TPV, } \\
\text { thermal } \\
\text { acceptability }\end{array}$ & \begin{tabular}{|c|} 
Heat stress \\
meter, \\
anemometer \\
and digital \\
hygrometer \\
\end{tabular} & $P M V=0.139 \times T_{o p}-3.625$ & $\begin{array}{c}11.1-25.5 \\
{ }^{\circ} \mathrm{C}\end{array}$ \\
\hline $\begin{array}{c}\text { Singh and } \\
\text { Chani (2017) }\end{array}$ & $\begin{array}{l}\text { Chandigarh } \\
\text { and Roorkee }\end{array}$ & Field study & $\begin{array}{l}\text { Multi } \\
\text { storey }\end{array}$ & Composite & $\begin{array}{l}\text { Summer, } \\
\text { winter, } \\
\text { monsoon }\end{array}$ & 55 & 71 & $\begin{array}{l}\text { Linear } \\
\text { regression }\end{array}$ & $\begin{array}{l}\text { RAT, RH, air } \\
\text { velocity, GT, } \\
\text { metabolic rate } \\
\text { and clothing }\end{array}$ & $\begin{array}{l}\text { Digital thermo- } \\
\text { hygrometer, K- } \\
\text { thermocouple, } \\
\text { Vane thermo- } \\
\text { anemometer }\end{array}$ & $\begin{array}{l}I S V=0.21 \times I_{g}-5.50 \\
T S I=1 / 3 W B T+3 / 4 T_{g}-2 V_{a}\end{array}$ & $\begin{array}{l}21.8- \\
31.4^{\circ} \mathrm{C}\end{array}$ \\
\hline $\begin{array}{c}\text { Netam et al. } \\
(2017)\end{array}$ & Chhattisgarh & $\begin{array}{c}\text { Simulation } \\
\text { study }\end{array}$ & $\begin{array}{c}\text { LIG } \\
\text { Houses }\end{array}$ & Hot-dry & Summer & - & - & CFD modelling & $\begin{array}{l}\text { Outdoor wind } \\
\text { speed, wind } \\
\text { direction, RH } \\
\text { and RAT } \\
\end{array}$ & CFD analysis & - & - \\
\hline $\begin{array}{l}\text { Kumar and } \\
\text { Dibakar } \\
\text { (2017) }\end{array}$ & $\begin{array}{l}\text { Bhubaneswa } \\
\text { r, Jodhpur } \\
\text { and New } \\
\text { Delhi }\end{array}$ & $\begin{array}{c}\text { Theoretical } \\
\text { modeling }\end{array}$ & - & $\begin{array}{l}\text { Hot-dry, } \\
\text { Composite } \\
\text { and Warm- } \\
\text { humid }\end{array}$ & Summer & - & - & $\begin{array}{c}\text { Experimentatio } \\
\mathrm{n} \text { and numerical } \\
\text { modeling }\end{array} \mid$ & $\begin{array}{c}\text { Average DBT } \\
\text { and average } \mathrm{RH}\end{array}$ & $\begin{array}{l}\text { Energyplus } \\
\text { simulation }\end{array}$ & - & - \\
\hline $\begin{array}{c}\text { Subramania } \\
\text { n et al. } \\
\text { (2017) }\end{array}$ & Thanjavur & $\begin{array}{c}\text { Experimen } \\
\text { tal study }\end{array}$ & $\mid \begin{array}{c}\text { Solar Passive } \\
\text { Design } \\
\text { house }\end{array}$ & $\begin{array}{l}\text { Warm- } \\
\text { humid }\end{array}$ & Summer & 2 & - & $\begin{array}{c}\text { Thermal } \\
\text { analysis of solar } \\
\text { passive } \\
\text { architecture }\end{array}$ & $\begin{array}{c}\text { RAT, RH, } \\
\text { ambient } \\
\text { temperature, } \\
\text { Air speed, solar }\end{array}$ & $\begin{array}{l}\text { Digital } \\
\text { anemometer, } \\
\text { solar power } \\
\text { meter, }\end{array}$ & - & $25-30^{\circ} \mathrm{C}$ \\
\hline
\end{tabular}




\begin{tabular}{|c|c|c|c|c|c|c|c|c|c|c|c|c|}
\hline & & & & & & & & & $\begin{array}{c}\text { radiations, wall } \\
\text { and roof } \\
\text { temperatures } \\
\text { Illumination } \\
\text { levels }\end{array}$ & $\begin{array}{l}\text { data logger, } \\
\text { Infrared } \\
\text { thermometer, } \\
\text { lux meter }\end{array}$ & & \\
\hline $\begin{array}{l}\text { Ponni and } \\
\text { Baskar } \\
(2017)\end{array}$ & $\begin{array}{c}\text { Chidambara } \\
\mathrm{m}\end{array}$ & $\begin{array}{c}\text { Experimen } \\
\text { tal study }\end{array}$ & $\begin{array}{l}\text { Multi } \\
\text { storey }\end{array}$ & $\begin{array}{l}\text { Warm- } \\
\text { humid }\end{array}$ & Summer & 1 & - & $\begin{array}{c}\text { Experimentatio } \\
\mathrm{n} \text { and physical } \\
\text { observation }\end{array}$ & $\begin{array}{l}\text { Roof and walls } \\
\text { temperatures }\end{array}$ & $\begin{array}{c}\text { Infra-red } \\
\text { thermometer }\end{array}$ & - & $26-32.4^{\circ} \mathrm{C}$ \\
\hline $\begin{array}{l}\text { Sthapak and } \\
\text { Bandyopadh } \\
\text { yay (2017) }\end{array}$ & Chhattisgarh & Case study & $\begin{array}{c}\text { Courtyard } \\
\text { houses }\end{array}$ & $\begin{array}{l}\text { Warm- } \\
\text { humid }\end{array}$ & $\begin{array}{c}\text { Summer and } \\
\text { monsoon }\end{array}$ & 20 & - & $\begin{array}{l}\text { Theoretical } \\
\text { description }\end{array}$ & \begin{tabular}{|} 
Construction \\
plan, courtyard \\
position \& wind \\
directions
\end{tabular} & - & - & - \\
\hline $\begin{array}{c}\text { Jaboyedoff et } \\
\text { al. (2017) }\end{array}$ & $\begin{array}{l}\text { Indore, } \\
\text { Chennai, } \\
\text { Rajkot }\end{array}$ & $\begin{array}{c}\text { Simulation } \\
\text { work }\end{array}$ & $\begin{array}{l}\text { Multi } \\
\text { storey }\end{array}$ & $\begin{array}{l}\text { Warm- } \\
\text { humid and } \\
\text { composite }\end{array}$ & Summer & - & - & $\begin{array}{c}\text { Energy } \\
\text { simulation }\end{array}$ & $\begin{array}{c}\text { U value, Glazing, } \\
\text { Window size, } \\
\text { Window to wall } \\
\text { ratio }\end{array}$ & $\begin{array}{l}\text { DesignBuilder } \\
\text { software }\end{array}$ & - & $\begin{array}{l}\text { Up to } \\
38.2^{\circ} \mathrm{C}\end{array}$ \\
\hline $\begin{array}{l}\text { Kapoor and } \\
\text { Tegar } \\
(2018)\end{array}$ & Bhopal & Field study & - & $\begin{array}{c}\text { Humid } \\
\text { subtropical }\end{array}$ & $\begin{array}{l}\text { Summer, } \\
\text { winter and } \\
\text { monsoon }\end{array}$ & - & 268 & $\begin{array}{l}\text { Weighted } \\
\text { parameters of } \\
\text { indoor } \\
\text { environment } \\
\text { using five star } \\
\text { rating scale } \\
\end{array}$ & \begin{tabular}{|c|} 
Lighting, \\
thermal \\
comfort, air \\
quality, visual \\
comfort and \\
acoustic \\
\end{tabular} & $\begin{array}{l}\text { Questionnaire } \\
\text { survey and } \\
\text { Architectural } \\
\text { Evaluation }\end{array}$ & ( & - \\
\hline $\begin{array}{l}\text { Thapa } \\
\text { (2019) }\end{array}$ & Darjeeling & Field study & $\begin{array}{l}\text { Single } \\
\text { storey }\end{array}$ & Cold & $\begin{array}{c}\text { Summer and } \\
\text { winter }\end{array}$ & 6 & 36 & $\begin{array}{l}\text { Polynomial } \\
\text { regression }\end{array}$ & $\begin{array}{l}\mathrm{RAT}, \mathrm{GT} \text { and } \\
\mathrm{RH}, \text { thermal } \\
\text { responses and } \\
\text { acceptability }\end{array}$ & $\begin{array}{c}\text { Heat stress } \\
\text { meter, } \\
\text { anemometer } \\
\text { and digital } \\
\text { hygrometer }\end{array}$ & $\begin{array}{l}T P V=0.091 \times T_{o p}-1.843(\text { Cold Season }) \\
T P V=0.077 \times T_{o p}-1.692(\text { Warm Season })\end{array}$ & $\begin{array}{c}11.1-25.5 \\
{ }^{\circ} \mathrm{C}\end{array}$ \\
\hline
\end{tabular}

